\title{
Phenetic diversity of alkaliphilic Bacillus strains: proposal for nine new species
}

\author{
Preben Nielsen, ${ }^{1,2} \dagger$ Dagmar Fritze ${ }^{1}$ and Fergus G. Priest ${ }^{2}$ \\ Author for correspondence: Fergus G. Priest. Tel: +44131449 5111. Fax: +441314513009.
}

\begin{abstract}
1 DSM - Deutsche Sammlung von Mikroorganismen und Zellkulturen $\mathrm{GmbH}$, Mascheroder Weg $1 \mathrm{~b}$, D-38124 Braunschweig, Germany

2 Department of Biological Sciences, Heriot-Watt University, Edinburgh EH14 4AS, UK
\end{abstract}

\begin{abstract}
One hundred and nineteen strains of alkaliphilic and alkalitolerant, aerobic endospore-forming bacteria were examined for 47 physiological and biochemical characters, and DNA base composition. Numerical analysis $(S$, and $S_{\mathrm{SM}}$ (UPGMA clustering) revealed 11 clusters that comprised three or more strains. Most of the phena were further characterized by analysis of carbohydrate utilization profiles using the API $50 \mathrm{CH}$ system, but strains of two taxa could not be cultured by this method. DNA reassociation studies showed that nine of the phena were homogeneous, but strains of phenon 4 and phenon 8 were each subdivided into two DNA hydridization groups. The strains could therefore be classified into 13 taxa plus a number of unassigned single-membered clusters. Two taxa were equated with Bacillus cohnii and $B$. alcalophilus and nine of the remainder are proposed as new species with the following names: B. agaradhaerens sp. nov., B. clarkii sp. nov., B. clausii sp. nov., B. gibsonii sp. nov., B. halmapalus sp. nov., B. halodurans comb. nov., $B$. horikoshii sp. nov., B. pseudalcalophilus sp. nov. and B. pseudofirmus sp. nov. Two taxa were insufficiently distinct to allow confident identification and these have therefore not been proposed as new species.
\end{abstract}

Keywords: alkaliphile, Bacillus, classification, nomenclature, taxonomy

\section{INTRODUCTION}

During an attempt to improve the enrichment medium for Vibrio cholerae, Vedder (1934) isolated aerobic, endospore-forming bacteria from human faeces, and later from animal faeces, which proved to be obligately alkaliphilic organisms (defined as a $\mathrm{pH}$ optimum for growth above $\mathrm{pH} 9$ and no growth at $\mathrm{pH} 7$ ). He proposed the name Bacillus alcalophilus for his strains and stated that he had been able to prove that life exists which not only tolerates, but depends on, a highly alkaline $\mathrm{pH}$. Today, these and other alkaliphilic Bacillus strains are of considerable industrial interest, particularly for the production of enzymes such as proteases for inclusion in laundry detergents (Aunstrup et al., 1972), xylanases for use in the pulp paper industry (Nakamura et al., 1993) and cyclodextrin glucanotransferase for cyclodextrin manufacture from starch (Kitamoto et al., 1992). These industrial applications have prompted the isolation of strains from a variety of alkaline environments (Horikoshi, 1991; Jones et al., 1994). The diverse bacteria

\footnotetext{
†Present address: Microbiology Section, The Royal Veterinary and Agricultural University, DK-1958 Fredericksberg, Copenhagen, Denmark. Abbreviation: MUG, 4-methylumbelliferyl $\beta$-D-glucuronide.
}

recovered are described simply as Bacillus sp. because there is no taxonomic framework to enable identification.

In addition to strict alkaliphiles, some Bacillus species are reported to tolerate a more or less alkaline $\mathrm{pH}$ and may be described as alkalitolerant (defined as growth at or above $\mathrm{pH} 9$ but also at $\mathrm{pH} 7$ ). The asporogenous bacterium $B$. balodenitrificans (Denariaz et al., 1989) is reported to grow between $\mathrm{pH} 5.8$ and 9.6 , but has an optimum in the neutral range at $\mathrm{pH} 7 \cdot 4$, and two thermophilic Bacillus species are reported to actually require a slightly alkaline $\mathrm{pH}$ : 'B. pallidus' (Scholz et al., 1988), which grows best at $\mathrm{pH} 8-8.5$ while also tolerating $\mathrm{pH} 7$; and ' $B$. thermocloacae' (Demharter \& Hensel, 1989), which requires a $\mathrm{pH}$ of $8-9$ and does not grow at $\mathrm{pH} 7$.

Taxonomic studies of truly alkaliphilic Bacillus strains have been few. Boyer et al. (1973) deemed two halotolerant and alkaliphilic Bacillus strains to be sufficiently related to the type strain of $B$. alcalophilus to justify subspecies status as ' $B$. alcalophilus subsp. balodurans', which necessitated transforming B. alcalophilus to 'B. alcalophilus subsp. alcalophilus'. This proposal was not included in the Approved Lists of Bacterial Names (Skerman et al., 1980). In later studies, strains of ' $B$. alcalophilus subsp. halodurans' were shown to be so different from the parent species, both genetically and physiologically, that separate species status 
was considered more appropriate (Fritze et al., 1990). Boyer et al. (1973) considered their strains to be distantly related to an alkaliphilic $B$. circulans strain described by Chislett \& Kushner (1961). This organism (strain RU 38) was later classified in a newly established alkaliphilic taxon, Bacillus cohnii (Spanka \& Fritze, 1993).

Some indication of the diversity within alkaliphilic Bacillus strains was provided by Gordon \& Hyde (1982). They characterized 174 alkaliphilic Bacillus strains of industrial importance after adaptation of the strains to neutral $\mathrm{pH}$ and allocated them to five physiologically defined groups. Four of these groups were sufficiently homogeneous to be retrieved in a later investigation with only a few compositional changes (Fritze et al., 1990). More recently, a strain of an alkaliphilic spore-forming organism (growth at $\mathrm{pH} \mathrm{8-10} \mathrm{but} \mathrm{not} \mathrm{at} \mathrm{pH}$ 7) was described which was so peculiar in its properties that the authors established a new genus for it: Ampbibacillus xylanus (Niimura et al., 1990). Its lack of cytochromes, quinones or catalase and its ability to form spores under aerobic as well as anaerobic conditions clearly distinguished this organism from the genera Bacillus, Clostridium and Sporolactobacillus.

The aim of the present work was to classify, at the species level, a collection of industrially important alkaliphilic Bacillus strains. Previous studies (Nielsen et al., 1994) had indicated that some of these bacteria were phylogenetically distinct from all validly described Bacillus species with the exceptions of the two alkaliphilic species B. alcalophilus and B. cobnii.

\section{METHODS}

Bacterial strains and culture conditions. The bacterial strains used in this study are listed in Table 1 . The strains were stored as a working collection at $5{ }^{\circ} \mathrm{C}$ on Nutrient agar (Difco) slopes adjusted to $\mathrm{pH} 9$ with $0 \cdot 1 \mathrm{M} \mathrm{NaHCO}_{3}$ or to $\mathrm{pH} 10$ with $0.1 \mathrm{M}$ $\mathrm{NaHCO}_{3}$ and $0.1 \mathrm{M} \mathrm{Na}_{2} \mathrm{CO}_{3}$ (sodium sesquicarbonate) and supplemented with $0 \cdot 1 \% \mathrm{MnSO}_{4}$ and $0.1 \% \mathrm{MgCl}_{2}$.

Phenotypic tests. Phenotypic tests were performed using the methods of Gordon et al. (1973), with media adjusted to approximately $\mathrm{pH} 10$ by the addition of $100 \mathrm{ml} \mathrm{l}^{-1}$ of $1 \mathrm{M}$ sodium sesquicarbonate buffer, except for the phenylalanine test, where $50 \mathrm{ml} \mathrm{l}^{-1}$ was used (Fritze et al., 1990). Tests were repeated where unclear or unexpected results were obtained.

pH range for growth. Nutrient agar (1 litre) was adjusted to various $\mathrm{pH}$ values: $\mathrm{pH} 6.0$ (adjusted by adding $\mathrm{HCl}$ ), $\mathrm{pH} 7.0$ (addition of $100 \mathrm{ml} 1.0 \mathrm{M}$ sodium phosphate buffer, $\mathrm{pH} 7 \cdot 0$ ), pH 8.0 (addition of $100 \mathrm{ml} 1.0 \mathrm{M} \mathrm{Na}_{2} \mathrm{HPO}_{4}$ ), $\mathrm{pH} 9.0$ (addition of $100 \mathrm{ml} 1 \mathrm{M} \mathrm{NaHCO}$ ), $\mathrm{pH} 10.0$ (addition of $100 \mathrm{ml} 1 \mathrm{M}$ sodium sesquicarbonate buffer, $\mathrm{pH} 10$ ). The agar media and buffers were autoclaved separately. Agar plates were inoculated by streaking to give discrete colonies, and growth intensity was interpreted on a scale from 1-5 after 1, 3 and $5 \mathrm{~d}$. Coding for the numerical analysis is described in the footnote to Table 2.

Utilization of carbohydrates. An early stationary phase culture in Nutrient broth (Difco) was centrifuged, and the cells resuspended in an equal amount of resuspension buffer $(2.19 \mathrm{~g}$ $\mathrm{Na}_{2} \mathrm{HPO}_{4} .2 \mathrm{H}_{2} \mathrm{O}, \quad 0.75 \mathrm{~g} \quad \mathrm{KH}_{2} \mathrm{PO}_{4}, \quad 1 \mathrm{~g} \mathrm{NaCl}, \quad 0.05 \mathrm{~g}$ $\mathrm{MgSO}_{4} .7 \mathrm{H}_{2} \mathrm{O}$ in $250 \mathrm{ml}$ distilled water). Resuspended culture $(0.5 \mathrm{ml})$ was added to a soft agar held at $42{ }^{\circ} \mathrm{C}$ and composed of $4 \mathrm{ml}$ each of two solutions. Solution 1 was $\mathrm{KNO}_{3}(2 \mathrm{~g})$, $\mathrm{Na}_{2} \mathrm{HPO}_{4} \cdot 2 \mathrm{H}_{2} \mathrm{O}(2 \mathrm{~g}), \mathrm{NaCl}(5 \mathrm{~g}), 100 \mathrm{ml} 1 \mathrm{M}$ sodium sesquicarbonate buffer $(\mathrm{pH} \mathrm{10 \cdot 0)}$ and water to $500 \mathrm{ml}$. After autoclaving, $2 \mathrm{ml}$ trace element solution $\left[0.1 \mathrm{~g} \mathrm{ZnSO}_{4} .7 \mathrm{H}_{2} \mathrm{O}\right.$, $0.03 \mathrm{~g} \mathrm{MnCl}_{2} .4 \mathrm{H}_{2} \mathrm{O}, 0.3 \mathrm{~g} \mathrm{H}_{3} \mathrm{BO}_{3}, 0.2 \mathrm{~g} \mathrm{CoCl}_{2} .6 \mathrm{H}_{2} \mathrm{O}, 0.01 \mathrm{~g}$ $\mathrm{CuCl}_{2} \cdot 2 \mathrm{H}_{2} \mathrm{O}, 0.02 \mathrm{~g} \mathrm{NiCl} \cdot 6 \mathrm{H}_{2} \mathrm{O}$ and $0.03 \mathrm{~g} \mathrm{Na}_{2} \mathrm{MoO}_{4} \cdot 2 \mathrm{H}_{2} \mathrm{O}$ dissolved in 11 distilled water with $12.8 \mathrm{~g}$ titriplex $\mathrm{I}$ (Merck) and $0 \cdot 1 \mathrm{~g} \mathrm{FeCl} \cdot 4 \mathrm{H}_{2} \mathrm{O}$ added], $2 \mathrm{ml}$ vitamin solution $(0 \cdot 2 \mathrm{mg}$ biotin, $2.0 \mathrm{mg}$ nicotinic acid, $1.0 \mathrm{mg}$ thiamin, $1.0 \mathrm{mg} 4$-aminobenzoate, $0.5 \mathrm{mg}$ pantothenate, $5.0 \mathrm{mg}$ pyridoxamine, $2.0 \mathrm{mg}$ cyanocobalamin, dissolved in $100 \mathrm{ml}$ water) and $2.5 \mathrm{ml} 2 \%$ $\mathrm{MgSO}_{4} \cdot 7 \mathrm{H}_{2} \mathrm{O}$ were added. Solution 2 was agar $(3 \mathrm{~g})$ autoclaved in $500 \mathrm{ml}$ distilled water. The API $50 \mathrm{CH}$ gallery (Biomérieux) was inoculated with two drops of the culture using a Pasteur pipette. Growth on the various carbohydrates was examined after 2, 7 and $14 \mathrm{~d}$ as recommended by the manufacturer.

Numerical analysis. The phenotypic data, except carbohydrate utilization results, were coded for numerical analysis as binary characters. Carbohydrate utilization data were excluded because some strains failed to grow in the test system, thus providing an incomplete data matrix. The $\mathrm{pH}$ range for growth was coded as described in the footnote to Table 2 and mol $\% \mathrm{G}+\mathrm{C}$ was coded by additive coding into six characters: $>34,>36,>38,>40$, $>42$ and $>44 \mathrm{~mol} \% \mathrm{G}+\mathrm{C}$. Data were analysed using the NTSYS software package (Exeter Software). Similarity matrices were calculated using the Simple Matching $\left(S_{\mathrm{SM}}\right)$ and Jaccard $\left(S_{s}\right)$ coefficients, and UPGMA dendrograms were drawn using the programs SIMEQUAL, and DRAWTREE of NTSYS.

Mol \% G + C determination. Minipreparations of DNA were prepared from cell mass (2-3 inoculation loops) taken from agar plates. Cells were washed in $1 \mathrm{ml}$ TES buffer $(50 \mathrm{mM}$ Tris, $5 \mathrm{mM}$ EDTA, $2.5 \%$ sucrose, $\mathrm{pH} 8$ ) and resuspended in $100 \mu \mathrm{l}$ TES buffer. A further $390 \mu \mathrm{l}$ TES containing $20 \mathrm{mg}$ lysozyme $\mathrm{ml}^{-1}$ was added and the tubes incubated at $37^{\circ} \mathrm{C}$ for at least $30 \mathrm{~min}$. Lysis buffer $(300 \mu \mathrm{l} 2 \mathrm{mM}$ EDTA, pH 8, containing $60 \%$ guanidinium thiocyanate and $12.5 \%$ SDS) was added followed by $250 \mu \mathrm{l} 7 \cdot 5 \mathrm{M}$ ammonium acetate. After mixing and chilling on ice for $10 \mathrm{~min}$, the tubes were centrifuged for $15 \mathrm{~min}$ and the supernatant removed to a new $2 \mathrm{ml}$ microfuge tube. The preparation was extracted with chloroform/isoamyl alcohol, precipitated with 2-propanol, washed with $70 \%$ ethanol, dried and resuspended in RNase buffer (Seldin \& Dubnau, 1985). The DNA was extracted with phenol and then with chloroform/ isoamyl alcohol, precipitated in ethanol, washed in $70 \%$ ethanol, dried and resuspended in water. An isolation typically yielded approximately $20 \mu \mathrm{g}$ DNA and about $90 \%$ of the RNA was removed. Hydrolysis and dephosphorylation of the DNA was carried out as described by Mesbah et al. (1989). Nucleoside samples, $25 \mu \mathrm{l}$ of $100 \mu \mathrm{g} \mathrm{ml}^{-1}$, were separated by reverse-phase HPLC at $26{ }^{\circ} \mathrm{C}$ using $0.6 \mathrm{M} \mathrm{NH} \mathrm{NH}_{4} \mathrm{PO}_{4}$ /acetonitrile $80: 6$ $(\mathrm{v} / \mathrm{v}), \mathrm{pH} 4.4$, as solvent and a flow rate of $0.7 \mathrm{ml} \mathrm{min}^{-1}$ (Tamaoka \& Komagata, 1984). The HPLC apparatus consisted of a high-pressure pump and UV detector (LKB 2150 and 2151). Separation was performed through a precolumn and an analytical column (Nucleosil 100-5C18 $20 \times 4 \mathrm{~mm}$ and $250 \times 4 \mathrm{~mm}$ respectively; MELZ VDS, Berlin). UV absorption was detected and analysed by an integrator (CR-3A, Shimadzu). $\mathrm{Mol} \% \mathrm{G}+\mathrm{C}$ was calculated from deoxyguanosine and deoxythymidine contents (Mesbah et al., 1989).

DNA hybridization. DNA for hybridizations was prepared from $300 \mathrm{ml}$ cultures in Tryptone soy broth (Difco) adjusted to $\mathrm{pH} 9$ or 10 as described above using the method of Seldin \& Dubnau (1985). The DNA concentration was determined by the diphenylamine assay (Johnson, 1981) with salmon testis DNA in the range $10-100 \mu \mathrm{g} \mathrm{ml}^{-1}$ as standard. Probe DNA was prepared by random-primed labelling of total chromosomal DNA with $5 \mu \mathrm{l}\left[{ }^{35} \mathrm{~S}\right] \mathrm{dATP}$ [600 Ci $(22 \cdot 2 \mathrm{TBq}) \mathrm{mmol}^{-1}, 50 \mu \mathrm{Ci}$ $(1.85 \mathrm{MBq})]$ using the Nonaprimer Kit (Appligene). Target DNA (100 ng per slot) was immobilized on nylon membranes 
Table 1. Bacterial strains included in this study

\begin{tabular}{|c|c|c|c|c|c|c|}
\hline \multicolumn{5}{|c|}{ Strain designation } & \multirow[t]{2}{*}{ Source $\int$} & \multirow[t]{2}{*}{ References $\|$} \\
\hline $\mathbf{P N}$ & Cluster $\dagger$ & NCIMB & DSM & Other & & \\
\hline 1 & $4 a$ & 10291 & 8714 & C 339 & River bank soil, Denmark & $a, d, e, j$ \\
\hline 2 & $4 a$ & 10282 & & C 323 & Field soil, Denmark & $a, d, e$ \\
\hline 3 & 1 & 10283 & 8715 & C 324 & Lake bank soil, Holstein, Germany & $a, d, e, j$ \\
\hline 4 & 7 & 10284 & & C 325 & Infection on perborate plate & $a, d, e, k$ \\
\hline 5 & $4 a$ & 10289 & & C 337 & Clay from field, Holstein, Germany & $a, d, e$ \\
\hline 6 & 1 & 10290 & & C 338 & Cementary soil, Denmark & $a, d, e$ \\
\hline 7 & 1 & 10292 & & C 340 & River bank soil, Denmark & $a, d, e$ \\
\hline 8 & $4 b$ & 10293 & & C 341 & Field soil, Denmark & $a, d, e$ \\
\hline 9 & 1 & 10294 & & C 342 & Garden soil, Denmark & $a, d, e$ \\
\hline 10 & 1 & 10295 & & C 343 & Garden soil, Denmark & $a, d, e$ \\
\hline 11 & 1 & 10296 & & C 346 & Chicken yard soil, Denmark & $a, d, e$ \\
\hline 12 & 1 & 10285 & & C 326 & Infection on perborate plate & $a, d, e$ \\
\hline 13 & 1 & 10297 & & C 347 & Deer manure, Denmark & $a, d, e$ \\
\hline 14 & 1 & 10298 & & C 348 & Chicken run soil & $a, d, e$ \\
\hline 15 & 1 & 10299 & & C 349 & Deer manure, Denmark & $a, d, e$ \\
\hline 16 & 1 & 10300 & & C 350 & Fresh lake water, Denmark & $a, d, e$ \\
\hline 17 & $5^{*}$ & 10301 & & C 351 & Chicken manure & $a, d, e$ \\
\hline 18 & 1 & 10302 & & C 352 & Ostrich manure, zoo & $a, d, e$ \\
\hline 19 & 1 & 10303 & & C 353 & Soil and leaves, Denmark & $a, d, e$ \\
\hline 20 & 5 & 10304 & & C 354 & Chicken yard soil & $a, d, e$ \\
\hline 21 & $1 *$ & 10305 & & C 355 & Chicken yard soil & $a, d, e$ \\
\hline 22 & $5^{*}$ & 10306 & & C 356 & Garden bark & $a, d, e$ \\
\hline 23 & 6 & 10309 & 8716 & C 360 & Garden soil, Denmark & $a, d, e, j$ \\
\hline 24 & 6 & 10317 & & C 372 & Clay from field, Holstein, Germany & $a, d, e$ \\
\hline 25 & $4 b^{*}$ & 10281 & & C 311 & Wood soil, Holstein, Germany & $a, d, e$ \\
\hline 26 & $4 b$ & 10288 & 8717 & C 336 & Horse and elephant manure & $a, d, e, j$ \\
\hline 27 & 1 & & & $\mathrm{RAB}$ & & $f, d, e$ \\
\hline 28 & 5 & 10307 & & C 357 & Chicken yard soil & $a, d, e$ \\
\hline 29 & 5 & 10308 & & C 358 & Chicken yard soil & $a, d, e$ \\
\hline 30 & 5 & 10310 & 8718 & C 364 & Lavatory cistern & $a, d, e, j$ \\
\hline 31 & 5 & 10311 & & C 365 & Liquid from tannery liming bath & $a, d, e$ \\
\hline 32 & 5 & 10312 & & C 366 & Baby faeces & $a, d, e$ \\
\hline 33 & $4 b$ & 10314 & & C 369 & Ostrich manure, zoo & $a, d, e$ \\
\hline 34 & 7 & 10318 & & C 373 & Garden soil, Denmark & $a, d, e, k$ \\
\hline 35 & 6 & 10319 & & C 374 & Clay from field, Holstein, Germany & $a, d, e$ \\
\hline 36 & 5 & 10320 & & C 375 & Ostrich manure & $a, d, e$ \\
\hline 37 & 5 & 10321 & & C 376 & Elephant manure & $a, d, e$ \\
\hline 38 & 5 & 10322 & & C 377 & Water from hippopotamus basin & $a, d, e$ \\
\hline 39 & 5 & 10323 & & C 378 & Tannery liming bath containers & $a, d, e$ \\
\hline 40 & 5 & 10324 & & C 410 & Tiger manure & $a, d, e$ \\
\hline 41 & 5 & 10325 & & C 411 & Pigeon manure & $a, d, e$ \\
\hline 42 & 5 & 10326 & & C 412 & Chicken yard soil & $a, d, e$ \\
\hline 43 & 6 & & 2512 & ATCC 21522, 221 & & $d, e, g$ \\
\hline 44 & 5 & & 2513 & ATCC 21591, A-59 & & $b, d, e$ \\
\hline 45 & $6^{*}$ & & 2514 & ATCC 21536, O-4 & & $d, e, b$ \\
\hline 46 & 6 & & 2515 & ATCC 21537, Y-76 & & $d, e, b$ \\
\hline 47 & 1 & & 2516 & ATCC 21592, A-40 & & $d, e$ \\
\hline 48 & 1 & & 2517 & ATCC $21593,124-1$ & & $d, e$ \\
\hline 49 & UC & & 2518 & ATCC 21594, 169 & & $d, e, b$ \\
\hline 50 & $\mathrm{UC}$ & & 2519 & ATCC 21595,135 & & $d, e, b$ \\
\hline 51 & $1^{*}$ & & 2520 & ATCC $21596,27-1$ & & $d, e$ \\
\hline 52 & $\mathrm{UC}$ & & 2521 & ATCC 21832, N1 & & $d$ \\
\hline 53 & $\mathrm{UC}$ & & 2522 & ATCC $21833, \mathrm{~N} 4$ & & $d$ \\
\hline 54 & $4 b$ & & 2523 & ATCC 31006,13 & & $d, e, b$ \\
\hline
\end{tabular}


Table 1. (cont.)

\begin{tabular}{|c|c|c|c|c|c|c|}
\hline \multicolumn{5}{|c|}{ Strain designation } & \multirow[t]{2}{*}{ Source $\$$} & \multirow[t]{2}{*}{ References $\|$} \\
\hline PN & Cluster $†$ & NCIMB & DSM & Other & & \\
\hline 55 & $4 b$ & & 2524 & ATCC $31007,17-1$ & & $d, e, b$ \\
\hline 56 & 6 & & 2525 & ATCC $31084, \mathrm{M}-29$ & & $e$ \\
\hline 57 & $10 \ddagger$ & 10438 & 2526 & NRS1554, NCTC 4554 & & $d, e, l$ \\
\hline 58 & 7 & 9218 & 2528 & RU 38 & Contamination, alkaline agar plate & $c, d, e, k$ \\
\hline 59 & $1 *$ & 10286 & 6930 & C 334 & River bank soil, Denmark & $a, d, e$ \\
\hline 60 & 7 & 10327 & 6932 & C 413 & Clay from field, Holstein, Germany & $a, d, e$ \\
\hline 61 & 5 & 10313 & 6939 & C 367 & Elephant manure & $a, d, e$ \\
\hline 62 & 5 & 10316 & 6940 & C 371 & Elephant manure & $a, d, e$ \\
\hline 63 & $5^{*}$ & & 6941 & $\mathrm{BC} 4$ & K. Aunstrup & $d, e$ \\
\hline 64 & UC & & 6942 & $\mathrm{BC} 7$ & K. Aunstrup & $d, e$ \\
\hline 65 & UC & & 6943 & PB 9 & K. Aunstrup & $d, e$ \\
\hline 66 & 5 & & 6944 & BB 16 & K. Aunstrup & $d, e$ \\
\hline 67 & 7 & & & $5 \mathrm{~A}$ & Water/sand, Wadi Natrun, Egypt & $k$ \\
\hline 68 & 7 & & & $5^{\prime} \mathrm{A}$ & Water/sand, Wadi Natrun, Egypt & $k$ \\
\hline 69 & 7 & & & $14 \mathrm{~B}$ & Water/sand, Wadi Natrun, Egypt & $k$ \\
\hline 70 & 7 & & & $15 \mathrm{~B}$ & Water/sand, Wadi Natrun, Egypt & $k$ \\
\hline 71 & 7 & & & $15^{\prime} \mathrm{B}$ & Water/sand, Wadi Natrun, Egypt & $k$ \\
\hline 72 & 1 & & & AF 1 & Stalactite cave, France & \\
\hline 73 & $1 *$ & & & AF 2 & Stalactite cave, France & \\
\hline 74 & $\mathrm{UC}$ & & & $\mathrm{Br}-\mathrm{B}$ & Soil, Brazil & \\
\hline 75 & $6^{*}$ & & & $\mathrm{Br}-\mathrm{E}$ & Soil, Brazil & \\
\hline 76 & 6 & & & $\mathrm{Br}-\mathrm{F}$ & Soil, Brazil & \\
\hline 77 & 1 & & 6950 & $\mathrm{BC} 3$ & K. Aunstrup & $d, e$ \\
\hline 78 & 7 & & 6913 & PB 38 & K. Aunstrup & $d, e, k$ \\
\hline 79 & $8 b$ & & 6951 & PB 19 & K. Aunstrup & $d, e$ \\
\hline 80 & 5 & & 497 & & 'B. alcalopbilus subsp. balodurans' & $b, d, e$ \\
\hline 81 & $1 *$ & & 7316 & $\mathrm{O} 2$ & Owens Lake, California, USA & $d$ \\
\hline 82 & 10 & & 7317 & O 3 & Owens Lake, California, USA & $d$ \\
\hline 83 & 7 & & 7318 & M 5 & Mono Lake, California, USA & $d$ \\
\hline 84 & UC & & 7319 & M 8 & Mono Lake, California, USA & $d, k$ \\
\hline 100 & $10^{*}$ & & & JA 14 & H. Outtrup & \\
\hline 101 & 10 & & & JA 16 & H. Outtrup & \\
\hline 102 & 3 & & 8720 & JP 395 & H. Outtrup & $j$ \\
\hline 103 & 3 & & & AC 66 & H. Outtrup & \\
\hline 104 & 3 & & & K 51 & H. Outtrup & \\
\hline 105 & 2 & & 8721 & AC 13 & H. Outtrup & $j$ \\
\hline 106 & 2 & & & K 320 & H. Outtrup & \\
\hline 107 & 2 & & & K 316 & H. Outtrup & \\
\hline 108 & 2 & & & AC 59 & H. Outtrup & \\
\hline 109 & 11 & & 8722 & PD 138 & H. Outtrup & $j$ \\
\hline 110 & 11 & & & H 55 & H. Outtrup & \\
\hline 111 & 11 & & & DP 182 & H. Outtrup & \\
\hline 112 & 11 & & & J 102 & H. Outtrup & \\
\hline 113 & $11 *$ & & & $\mathrm{~J} 114$ & H. Outtrup & \\
\hline 114 & $\mathrm{UC}$ & & & $\mathrm{J} 20$ & H. Outtrup & \\
\hline 117 & $8 b^{*}$ & & & SF 16 & H. Outtrup & \\
\hline 118 & $8 \mathrm{a}$ & & 8723 & JP 170 & H. Outtrup & $j$ \\
\hline 119 & $8 b$ & & & $874 X$ & H. Outtrup & \\
\hline 120 & $8 b$ & & & JP 75 & H. Outtrup & \\
\hline 121 & $8 b$ & & 8719 & JP 277 & H. Outtrup & $j$ \\
\hline 122 & $8 b$ & & & MHas 96 & H. Outtrup & \\
\hline 123 & $8 b^{*}$ & & & PD 456 & H. Outtrup & \\
\hline 124 & $8 \mathrm{a}$ & & & JP 216 & H. Outtrup & \\
\hline 125 & $\mathrm{UC}$ & & & BC 7 & K. Aunstrup & \\
\hline
\end{tabular}


Table 1. (cont.)

\begin{tabular}{|c|c|c|c|c|c|c|}
\hline \multicolumn{5}{|c|}{ Strain designation } & \multirow[t]{2}{*}{ Source $\$$} & \multirow[t]{2}{*}{ References $\|$} \\
\hline PN & Cluster & NCIMB & DSM & Other & & \\
\hline 127 & 2 & & & AT 67 & H. Outtrup & \\
\hline 129 & 2 & & & AP 72 & H. Outtrup & \\
\hline 130 & 9 & & & DP 155 & H. Outtrup & \\
\hline 131 & $10^{*}$ & & 8724 & DP 45 & H. Outtrup & $j$ \\
\hline 132 & 9 & & & DP 100 & H. Outtrup & \\
\hline 133 & 11 & & & J 26 & H. Outtrup & \\
\hline 135 & 9 & & & $\mathrm{~J} 463$ & H. Outtrup & \\
\hline 136 & $9^{*}$ & & & J 466 & H. Outtrup & \\
\hline 137 & 9 & & 8725 & DP 44 & H. Outtrup & $j$ \\
\hline 138 & 10 & & & DP 469 & H. Outtrup & \\
\hline 139 & 10 & & & DP 486 & H. Outtrup & \\
\hline
\end{tabular}

† Strains marked by an asterisk were included in the given cluster by $S_{\mathrm{J}} /$ UPGMA analysis but showed less than $65 \%$ DNA hybridization to the reference strain. UC, unclustered.

$\ddagger$ This strain was recovered as a single-membered cluster by $S_{\mathrm{J}} /$ UPGMA analysis but DNA hybridization revealed that it was a member of this taxon.

$\S K$. Aunstrup and H. Outtrup, Novo Nordisk A/S, Bagsvaerd, Denmark.

\| References: $a$, Aunstrup et al. (1971); b, Boyer et al. (1973); c, Chislett \& Kushner (1961); d, Fritze et al. (1990); e, Gordon \& Hyde (1982); $f$, Guffanti (1983); g, Horikoshi (1971); $b$, Horikoshi (1975); i, Horikoshi \& Ikeda (1997); j, Nielsen et al. (1994); $k$, Spanka \& Fritze (1993); l, Vedder (1934).

(Nytran N, Schleicher and Schuell) using the slot-blot system. Hybridizations were carried out overnight at $62^{\circ} \mathrm{C}$ (Alexander \& Priest, 1989). Percentage reassociation was calculated from the radioactivity of the hybrids relative to homologous controls and with subtraction of unspecific background radiation occurring from non-homologous (salmon testis DNA) hybridization (Seldin \& Dubnau, 1985).

\section{RESULTS}

\section{Phenetic characterization}

Our initial studies revealed that the alkaliphilic strains included in this study did not produce acid from glucose when examined using the classical test procedures (Gordon et al., 1973) adapted for use at alkaline $\mathrm{pH}$. Sugar fermentation tests were therefore excluded from the study. Moreover, some strains, notably those of cluster 3 and cluster 7 (B. cobnii), failed to grow or produce a reliable indication of carbon utilization in the modified API $50 \mathrm{CH}$ tests; since these data were incomplete they were excluded from the numerical analysis. The numerical classification was therefore based on 47 characters including DNA base composition, which was coded as six binary characters as described in Methods. Most of these tests had previously been shown to be useful for classification of alkaliphilic Bacillus strains (Fritze et al., 1990).

Despite the relatively few tests, the 119 test strains were consistently allocated to 11 clusters in analyses using the Jaccard (at the $80 \%$ similarity level) and simple matching (at the $90 \%$ similarity level) coefficients with average linkage (UPGMA) cluster analysis. The only differences between the two classifications were that strain PN-10 clustered with phenon 1 and strain PN-82 with phenon 10 in the $S_{\mathrm{J}}$ dendrogram but both were recovered as singlemembered clusters by $S_{\mathrm{SM}}$ analysis. Subsequent evaluation of these results by DNA hybridization revealed that the $S_{J}$ allocation was correct for strain PN-10 (DNA could not be prepared from strain $\mathrm{PN}-82$ ) and therefore this classification is shown in Fig. 1. Nine strains were recovered as single-membered clusters and two strains (PN-64 and PN-125) as a doublet. Biochemical and physiological characteristics of clusters $1-11$ are shown in Table 2.

Determination of carbohydrate utilization required development of a minimal medium. Ammonium was ineffective as a nitrogen source, probably because ammonia gas was released at the high $\mathrm{pH}$, and therefore nitrate was used in a minimal medium (see Methods) at $\mathrm{pH}$ 10. The patterns of carbon source utilization are shown in Table 3. Utilization of aesculin could not be detected because the substrate was unstable under the alkaline conditions. Eight carbohydrate substrates were catabolized by essentially all strains tested. These were: cellobiose, fructose, glucose, glycerol (with the exception of group 8a), maltose, mannitol, sucrose and trehalose. Conversely, no growth was obtained for any strains on the following substrates: adonitol, arbutin, L-arabitol, Dfucose, L-fucose, inulin, 5-ketogluconate, sorbose and Lxylose, The percentage distribution of positive characters for the taxa for the remaining 31 substrates are listed in Table 3.

The clusters derived by phenotypic analysis were, with the exception of $B$. cobnii (phenon 7), which had been previously studied by Spanka \& Fritze (1993), evaluated by DNA hybridization. The same reference strains were 


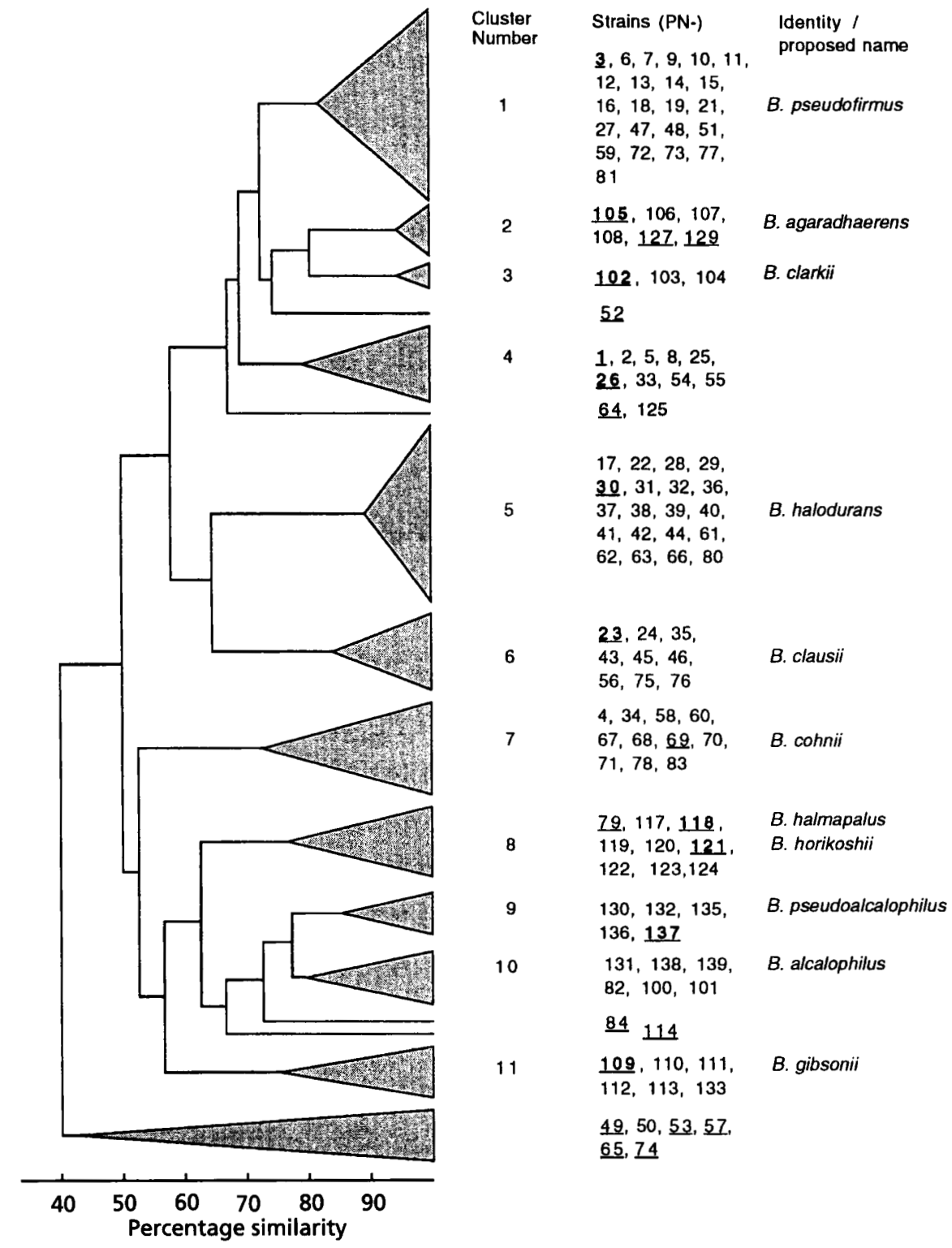

Fig. 1. Abbreviated dendrogram showing the allocation of strains to clusters based on the $S_{\mathrm{J}} / \mathrm{UPGMA}$ analysis of the biochemical and physiological characteristics. Bold underlined strain numbers indicate those strains for which the full $16 \mathrm{~S}$ rRNA sequence has been determined (Nielsen et al., 1994); underlined strain numbers indicate those for which a partial $16 \mathrm{~S}$ rRNA sequence has been determined (unpublished).

used as in the previous rRNA sequence analysis study of these bacteria (Nielsen et al., 1994). The rRNA study had indicated that clusters 4 and 8 may be heterogeneous and therefore two reference strains were chosen for each of these clusters (see Table 4). In general, the classifications based on phenetic analysis and DNA hybridization were consistent, although there were some discrepancies, as described below and in the descriptions of phena.

DNA from none of the reference strains hybridized significantly with DNA from any other reference strain, thus supporting the integrity of the 11 clusters. Clusters 4 and 8 were each shown to represent at least two DNA hybridization groups, which are consequently labelled a and $b$ in Tables 1,2 and 3. DNA from only one of the single-membered clusters hybridized significantly with DNA from any of the reference strains (data not shown), supporting the recovery of these strains outside the 11 clusters in the numerical analysis. The exception was strain PN-57, which showed high binding to DNA from B. alcalophilus DSM $485^{\mathrm{T}}$ and was thus considered as a member of cluster 10 .

\section{Analysis and descriptions of the groupings of the alkaliphilic Bacillus strains}

Phenon 1. This large group of 23 strains, derived from 
Table 2. Biochemical and physiological characteristics of clusters shown in the $S_{J} / U P G M A$ analysis modified according to the DNA hybridization results

\begin{tabular}{|c|c|c|c|c|c|c|c|c|c|c|c|c|c|}
\hline $\begin{array}{r}\text { Cluster ... } \\
\text { No. of strains . }\end{array}$ & $\begin{array}{r}1 \\
18\end{array}$ & $\begin{array}{l}2 \\
4\end{array}$ & $\begin{array}{l}3 \\
3\end{array}$ & $\begin{array}{l}4 a^{*} \\
3\end{array}$ & $\begin{array}{l}4 b \\
5\end{array}$ & $\begin{array}{r}5 \\
16\end{array}$ & $\begin{array}{l}6 \\
6\end{array}$ & $\begin{array}{r}7 \\
11\end{array}$ & $\begin{array}{l}8 a^{*} \\
2\end{array}$ & $\begin{array}{l}8 b \\
4\end{array}$ & $\begin{array}{l}9 \\
4\end{array}$ & $\begin{array}{r}10 \\
5\end{array}$ & $\begin{array}{r}11 \\
5\end{array}$ \\
\hline \multicolumn{14}{|l|}{ Hydrolysis of: } \\
\hline Hippurate & 0 & 0 & 100 & 0 & 20 & 6 & 0 & 100 & 100 & 100 & 0 & 0 & 0 \\
\hline MUG & 0 & 0 & 0 & 0 & 0 & 0 & 0 & 100 & 0 & 0 & 0 & 0 & 100 \\
\hline Pullulan & 11 & 50 & 0 & 60 & 100 & 100 & 0 & 100 & 100 & 100 & 100 & 100 & 0 \\
\hline Starch & 100 & 100 & 0 & 100 & 100 & 100 & 100 & 100 & 100 & 100 & 100 & 100 & 0 \\
\hline Tween 20 & 0 & 0 & 0 & 0 & 0 & 12 & 0 & 0 & 0 & 0 & 0 & 20 & 0 \\
\hline Tween 40 & 100 & 100 & 100 & 0 & 0 & 100 & 0 & 100 & 0 & 75 & 75 & 100 & 60 \\
\hline Tween 60 & 100 & 100 & 100 & 0 & 0 & 100 & 0 & 100 & 0 & 75 & 75 & 100 & 60 \\
\hline \multicolumn{14}{|l|}{ Deamination of: } \\
\hline Phenylalanine & 100 & 0 & 0 & 0 & 0 & 0 & 0 & 0 & 0 & 0 & 0 & 0 & 0 \\
\hline $\begin{array}{l}\text { Reduction of: } \\
\text { Nitrate }\end{array}$ & 0 & 100 & 100 & 0 & 0 & 12 & 100 & 100 & 0 & 0 & 0 & 20 & 40 \\
\hline \multicolumn{14}{|l|}{ pH optimum $\dagger$} \\
\hline 7 & 11 & 0 & 0 & 100 & 100 & 86 & 100 & 54 & 100 & 100 & 0 & 0 & 100 \\
\hline$>9$ & 100 & 100 & 100 & 100 & 100 & 100 & 0 & 100 & 0 & 0 & 100 & 100 & 0 \\
\hline 10 & 17 & 100 & 100 & 67 & 0 & 95 & 0 & 0 & 0 & 0 & 100 & 80 & 0 \\
\hline$>10$ & 6 & 100 & 100 & 0 & 0 & 0 & 0 & 0 & 0 & 0 & 0 & 0 & 0 \\
\hline \multicolumn{14}{|l|}{ Growth at: } \\
\hline $10^{\circ} \mathrm{C}$ & 100 & 100 & 0 & 100 & 100 & 0 & 0 & 78 & 100 & 100 & 100 & 100 & 80 \\
\hline $40^{\circ} \mathrm{C}$ & 100 & 100 & 100 & 0 & 100 & 100 & 100 & 100 & 100 & 100 & 100 & 100 & 0 \\
\hline $45^{\circ} \mathrm{C}$ & 100 & 100 & 100 & 0 & 0 & 100 & 100 & 100 & 0 & 0 & 0 & 0 & 0 \\
\hline $50^{\circ} \mathrm{C}$ & 0 & 0 & 0 & 0 & 0 & 100 & 100 & 0 & 0 & 0 & 0 & 0 & 0 \\
\hline $55^{\circ} \mathrm{C}$ & 0 & 0 & 0 & 0 & 0 & 100 & 0 & 0 & 0 & 0 & 0 & 0 & 0 \\
\hline \multicolumn{14}{|l|}{ Growth in $\mathrm{NaCl}$ : } \\
\hline $5 \%$ & 100 & 100 & 100 & 100 & 100 & 100 & 100 & 100 & 0 & 100 & 100 & 100 & 100 \\
\hline $7 \%$ & 100 & 100 & 100 & 100 & 100 & 100 & 100 & 100 & 0 & 100 & 100 & 100 & 100 \\
\hline $8 \%$ & 100 & 100 & 100 & 100 & 100 & 100 & 100 & 36 & 0 & 100 & 100 & 100 & 100 \\
\hline $9 \%$ & 100 & 100 & 100 & 100 & 100 & 100 & 84 & 36 & 0 & 50 & 100 & 0 & 100 \\
\hline $10 \%$ & 100 & 100 & 100 & 100 & 100 & 100 & 84 & 0 & 0 & 0 & 100 & 0 & 40 \\
\hline $11 \%$ & 100 & 100 & 100 & 100 & 100 & 100 & 0 & 0 & 0 & 0 & 0 & 0 & 20 \\
\hline $12 \%$ & 100 & 100 & 100 & 100 & 100 & 100 & 0 & 0 & 0 & 0 & 0 & 0 & 20 \\
\hline $13 \%$ & 100 & 100 & 100 & 100 & 100 & 35 & 0 & 0 & 0 & 0 & 0 & 0 & 0 \\
\hline $14 \%$ & 100 & 100 & 100 & 100 & 100 & 0 & 0 & 0 & 0 & 0 & 0 & 0 & 0 \\
\hline $15 \%$ & 100 & 100 & 100 & 100 & 100 & 0 & 0 & 0 & 0 & 0 & 0 & 0 & 0 \\
\hline $16 \%$ & 100 & 100 & 100 & 0 & 20 & 0 & 0 & 0 & 0 & 0 & 0 & 0 & 0 \\
\hline $17 \%$ & 78 & 25 & 67 & 0 & 0 & 0 & 0 & 0 & 0 & 0 & 0 & 0 & 0 \\
\hline $18 \% \ddagger$ & 0 & - & 33 & 0 & 0 & 0 & 0 & 0 & 0 & 0 & 0 & 0 & 0 \\
\hline
\end{tabular}

All strains were positive for the following tests: casein and gelatin hydrolysis, growth at 15, 20, 30 and $37^{\circ} \mathrm{C}$, and $\mathrm{pH}$ optimum for growth $>8$ (see below). They were all negative in the following reactions: hydrolysis of Tween 80 , and growth at $50^{\circ} \mathrm{C}$ and in $20 \% \mathrm{NaCl}$ (strains $\mathrm{PN}-64$ and $\mathrm{PN}-125$ positive for the last mentioned).

* Phena 4 and 8 split into two subclusters as indicated by DNA hybridization results. All other clusters (with the exception of cluster 7) are based on strains with $>65 \%$ homology to the reference strain.

$\dagger \mathrm{pH}$ 'optimum' for growth coded as positive in ' $>8$ ' indicates that growth at $\mathrm{pH} 8$ was estimated to be greater than at $\mathrm{pH} 7$ (all strains displayed this attribute) and ' $>9$ ' indicates growth at $\mathrm{pH} 9$ greater than at $\mathrm{pH} 8$. ' 10 ' and ' $>10$ ' indicate that growth at $\mathrm{pH} 10$ was greater than at $\mathrm{pH} 8$ and $\mathrm{pH} 9$ respectively. For $\mathrm{pH} 7$, a positive record indicates growth at neutrality.

$\ddagger$ A dash indicates no data available for that entry.

soils from northern Europe, formed a discrete cluster at $82 \% S_{\mathrm{J}}$. Eighteen of these strains showed $>65 \%$ DNA hybridization with strain PN-3 whereas four strains hybridized to a lesser extent with the reference strain (see Table 4). The characteristics of these bacteria are shown in Tables 2 and 3 . They were particularly notable for their 
Table 3. Utilization of carbohydrate substrates by strains of clusters shown in the S,/UPGMA analysis modified according to the results of DNAVDNA hybridization

\begin{tabular}{|c|c|c|c|c|c|c|c|c|c|c|c|c|}
\hline \multirow[t]{3}{*}{ Substrate } & \multirow{3}{*}{$\begin{array}{r}\text { Cluster ... } \\
\text { No. of strains ... }\end{array}$} & 1 & 2 & $4 a$ & $4 b$ & 5 & 6 & $8 \mathbf{a}$ & $8 b *$ & 9 & $10 \dagger$ & 11 \\
\hline & & 18 & 4 & 3 & 5 & 16 & 6 & 2 & 3 & 4 & 3 & 5 \\
\hline & & \multicolumn{11}{|c|}{ Percentage positive } \\
\hline 2 & Erythritol & 0 & 0 & 0 & 0 & 0 & 50 & 0 & 0 & 0 & 0 & 0 \\
\hline 3 & D-Arabinose & 22 & 100 & 0 & 20 & 44 & 50 & 0 & 0 & 25 & 67 & 20 \\
\hline 4 & L-Arabinose & 5 & 100 & 0 & 40 & 94 & 100 & 0 & 0 & 100 & 100 & 100 \\
\hline 5 & Ribose & 89 & 100 & 0 & 40 & 100 & 100 & 0 & 33 & 100 & 100 & 100 \\
\hline 6 & D-Xylose & 55 & 100 & 0 & 20 & 100 & 100 & 50 & 33 & 100 & 33 & 40 \\
\hline 9 & Methyl $\beta$-D-xyloside & 0 & 0 & 0 & 0 & 31 & 33 & 0 & 0 & 75 & 100 & 40 \\
\hline 10 & Galactose & 5 & 100 & 33 & 60 & 100 & 83 & 0 & 0 & 100 & 100 & 40 \\
\hline 13 & Mannose & 55 & 100 & 33 & 60 & 100 & 100 & 100 & 33 & 0 & 33 & 100 \\
\hline 15 & Rhamnose & 0 & 60 & 0 & 0 & 100 & 100 & 0 & 0 & 75 & 100 & 40 \\
\hline 16 & Dulcitol & 0 & 0 & 0 & 20 & 0 & 100 & 0 & 0 & 0 & 0 & 0 \\
\hline 17 & Inositol & 5 & 0 & 0 & 60 & 100 & 17 & 0 & 0 & 0 & 33 & 0 \\
\hline 19 & Sorbitol & 0 & 50 & 0 & 0 & 0 & 100 & 0 & 0 & 0 & 0 & 0 \\
\hline 20 & Methyl $\alpha$-D-mannoside & 0 & 25 & 33 & 0 & 0 & 67 & 0 & 0 & 0 & 33 & 40 \\
\hline 21 & Methyl $\alpha$-D-glucoside & 17 & 100 & 33 & 20 & 94 & 100 & 0 & 67 & 100 & 100 & 0 \\
\hline 22 & $N$-Acetylglucosamine & 100 & 100 & 33 & 80 & 100 & 100 & 100 & 100 & 0 & 100 & 0 \\
\hline 23 & Amygdalin & 22 & 100 & 33 & 80 & 100 & 100 & 100 & 33 & 100 & 100 & 60 \\
\hline 26 & Salicin & 67 & 100 & 67 & 60 & 100 & 100 & 50 & 0 & 100 & 100 & 100 \\
\hline 29 & Lactose & 0 & 50 & 0 & 0 & 100 & 83 & 0 & 0 & 100 & 100 & 100 \\
\hline 30 & Melibiose & 0 & 100 & 33 & 60 & 100 & 100 & 0 & 0 & 0 & 100 & 100 \\
\hline 34 & Melezitose & 0 & 25 & 33 & 60 & 100 & 100 & 0 & 0 & 0 & 33 & 100 \\
\hline 35 & Raffinose & 0 & 100 & 33 & 60 & 94 & 100 & 0 & 0 & 0 & 100 & 100 \\
\hline 36 & Starch & 95 & 100 & 0 & 20 & 100 & 100 & 100 & 100 & 100 & 100 & 0 \\
\hline 37 & Glycogen & 67 & 100 & 0 & 0 & 100 & 100 & 100 & 100 & 100 & 100 & 0 \\
\hline 38 & Xylitol & 5 & 0 & 0 & 20 & 81 & 100 & 0 & 0 & 0 & 0 & 0 \\
\hline 39 & Gentiobiose & 11 & 10 & 0 & 20 & 56 & 83 & 0 & 67 & 100 & 100 & 100 \\
\hline 40 & D-Turanose & 39 & 100 & 0 & 20 & 94 & 100 & 100 & 67 & 100 & 100 & 100 \\
\hline 41 & D-Lyxose & 22 & 100 & 0 & 20 & 87 & 100 & 0 & 0 & 75 & 67 & 0 \\
\hline 42 & D-Tagatose & 0 & 75 & 0 & 0 & 6 & 100 & 0 & 0 & 75 & 67 & 0 \\
\hline 45 & D-Arabitol & 16 & 75 & 0 & 40 & 75 & 83 & 0 & 0 & 0 & 33 & 0 \\
\hline 47 & Gluconate & 61 & 0 & 0 & 20 & 100 & 17 & 50 & 67 & 25 & 0 & 0 \\
\hline 48 & 2-Ketogluconate & 5 & 100 & 33 & 20 & 100 & 83 & 50 & 67 & 50 & 0 & 20 \\
\hline
\end{tabular}

All strains assigned to clusters were positive for the following substrates: cellobiose, fructose, glucose, glycerol, maltose, sucrose and trehalose; and negative for adonitol, L-arabitol, D-fucose, L-fucose, inulin, 2-ketogluconate, L-xylose.

* Strain PN-120 unable to grow in the modified API system.

† Strain PN-57 unable to grow in the modified API system.

high $\mathrm{NaCl}$ tolerance and ability to deaminate phenylalanine. The morphology of the reference strain showed typical oval endospores in a non-swollen sporangium (Fig. 2a).

Phenon 2. These six bacteria, like those of phenon 3 , were obtained from soil or mud samples and had a similar requirement for sodium ions and $\mathrm{pH}$. The mean DNA base composition of these bacteria was lower than that for strains of phenon $3(39.3 \mathrm{~mol} \% \mathrm{G}+\mathrm{C}$ compared with $42.6 \mathrm{~mol} \%$; see Table 4). Four of these strains formed a distinct group based on phenotype and DNA hybridization ( $>73 \%$ DNA reassociation), but DNA could not be isolated from the other two strains, PN-127 and PN-129. The reference strain produced oval spores which clearly distend the sporangium (Fig. 2b). These bacteria can be distinguished by their ability to hydrolyse cellulose and xylan effectively ( $H$. Outtrup, personal communication).

Phenon 3. The three strains in this taxon, all isolated from soil or mud samples, formed a tight cluster at $92 \% S_{\mathrm{J}}$. DNA from the three strains showed a high degree of reassociation and close similarity in $\mathrm{mol} \% \mathrm{G}+\mathrm{C}$ composition (Table 4). They were moderately halophilic, showing good growth at $15 \% \mathrm{NaCl}$. Indeed, physio- 
Table 4. Base composition and hybridization of DNA to reference DNA from strains representing the phenotypic clusters

All figures in parentheses are standard deviations.

\begin{tabular}{|c|c|c|c|c|c|c|c|c|c|c|c|c|c|c|}
\hline \multirow[t]{2}{*}{ Cluster } & \multirow[t]{2}{*}{ Strain $\dagger$} & \multirow[t]{2}{*}{ Mol $\%$ G + C } & \multicolumn{12}{|c|}{ Hybridization to reference DNA (\%) } \\
\hline & & & $\begin{array}{c}1 \\
\text { PN-3 }\end{array}$ & $\begin{array}{c}2 \\
\text { PN-105 }\end{array}$ & $\begin{array}{c}3 \\
\text { PN-102 }\end{array}$ & $\begin{array}{c}4 \mathrm{a} \\
\text { PN-1 }\end{array}$ & $\begin{array}{c}\text { 4b } \\
\text { PN-26 }\end{array}$ & $\begin{array}{c}5 \\
\text { PN-30 }\end{array}$ & $\begin{array}{c}6 \\
\text { PN-23 }\end{array}$ & $\begin{array}{c}\text { 8a } \\
\text { PN-118 }\end{array}$ & $\begin{array}{c}\text { 8b } \\
\text { PN-121 }\end{array}$ & $\begin{array}{c}9 \\
\text { PN-137 }\end{array}$ & $\begin{array}{c}10 \\
\text { DSM } 485\end{array}$ & $\begin{array}{c}11 \\
\text { PN-109 }\end{array}$ \\
\hline 1 & $\begin{array}{l}18 \text { strains } \\
\text { *PN-3 } \\
\text { PN-81 } \\
\text { PN-21 } \\
\text { PN-73 } \\
\text { PN-51 } \\
\text { PN-59 }\end{array}$ & $\begin{array}{l}39 \cdot 6(0 \cdot 4) \\
39 \cdot 6 \\
39 \cdot 6 \\
40 \cdot 2 \\
40 \cdot 7 \\
40 \cdot 4 \\
39 \cdot 1\end{array}$ & $\begin{array}{c}95(16) \\
100 \\
60 \\
36 \\
31 \\
27 \\
23\end{array}$ & $\begin{array}{r}4 \\
\\
\end{array}$ & 5 & 12 & 16 & 4 & 15 & 8 & 5 & 5 & 4 & 14 \\
\hline 2 & $\begin{array}{l}4 \text { strains } \\
\text { *PN-105 }\end{array}$ & $\begin{array}{l}39 \cdot 3(0 \cdot 2) \\
39 \cdot 2\end{array}$ & 18 & $\begin{array}{l}82(11) \\
100\end{array}$ & 16 & 13 & 13 & 4 & 10 & 9 & 7 & 6 & 4 & 13 \\
\hline 3 & $\begin{array}{l}3 \text { strains } \\
\text { *PN-102 }\end{array}$ & $\begin{array}{l}42 \cdot 6(0 \cdot 2) \\
42 \cdot 4\end{array}$ & 9 & 3 & $\begin{array}{l}93(9) \\
100\end{array}$ & 13 & 14 & 3 & 11 & 10 & 4 & 7 & 12 & 18 \\
\hline 4 & $\begin{array}{l}\text { a: } 3 \text { strains } \\
* \text { PN-1 } \\
\text { b: } 5 \text { strains } \\
\text { *PN-26 } \\
\text { PN-25 }\end{array}$ & $\begin{array}{l}38 \cdot 6(0 \cdot 2) \\
38 \cdot 4 \\
39 \cdot 5(0 \cdot 2) \\
39 \cdot 2 \\
38 \cdot 2\end{array}$ & $\begin{array}{l}7 \\
6\end{array}$ & $\begin{array}{l}4 \\
4\end{array}$ & $\begin{array}{r}7 \\
11\end{array}$ & $\begin{array}{l}85(11) \\
100 \\
17(5) \\
23 \\
11\end{array}$ & $\begin{array}{c}15(1) \\
13 \\
87(9) \\
100 \\
11\end{array}$ & $\begin{array}{l}7 \\
5\end{array}$ & $\begin{array}{l}10 \\
19\end{array}$ & $\begin{array}{r}9 \\
11\end{array}$ & $\begin{array}{l}6 \\
6\end{array}$ & $\begin{array}{l}5 \\
8\end{array}$ & $\begin{array}{l}7 \\
7\end{array}$ & $\begin{array}{l}12 \\
16\end{array}$ \\
\hline 5 & $\begin{array}{l}16 \text { strains } \\
* \text { PN-30 } \\
\text { PN-17 } \\
\text { PN-63 } \\
\text { PN-22 } \\
\text { PN-44 } \\
\text { PN-38 }\end{array}$ & $\begin{array}{l}42 \cdot 6(0 \cdot 4) \\
42 \cdot 8 \\
42 \cdot 6 \\
42 \cdot 7 \\
42 \cdot 6 \\
42 \cdot 8 \\
42 \cdot 6\end{array}$ & 9 & 5 & 11 & 24 & 29 & $\begin{array}{c}87(13) \\
100 \\
60 \\
63 \\
57 \\
51 \\
37\end{array}$ & 22 & 12 & 8 & 8 & 5 & 19 \\
\hline 6 & $\begin{array}{l}6 \text { strains } \\
{ }^{*} \text { PN-23 } \\
\text { PN-56 } \\
\text { PN-45 } \\
\text { PN-75 }\end{array}$ & $\begin{array}{l}43 \cdot 7(0 \cdot 8) \\
42 \cdot 8 \\
43 \cdot 5 \\
43 \cdot 2 \\
45 \cdot 3\end{array}$ & 5 & 4 & 12 & 19 & 25 & 12 & $\begin{array}{c}78(10) \\
100 \\
63 \\
61 \\
13\end{array}$ & 12 & 3 & 7 & 10 & 11 \\
\hline 8 & $\begin{array}{l}\text { a: } 2 \text { strains } \\
\text { *PN-118 } \\
\text { b: } 4 \text { strains } \\
\text { *PN-121 } \\
\text { PN-117 } \\
\text { PN-123 }\end{array}$ & $\begin{array}{l}38 \cdot 6 \\
38 \cdot 6 \\
41 \cdot 5(0 \cdot 4) \\
41 \cdot 3 \\
40 \cdot 6 \\
40 \cdot 6\end{array}$ & $\begin{array}{r}20 \\
5\end{array}$ & $\begin{array}{l}5 \\
4\end{array}$ & $\begin{array}{l}34 \\
13\end{array}$ & $\begin{array}{l}15 \\
12\end{array}$ & $\begin{array}{l}20 \\
14\end{array}$ & $\begin{array}{l}9 \\
9\end{array}$ & $\begin{array}{l}39 \\
12\end{array}$ & $\begin{array}{c}96 \\
100 \\
24(7) \\
18 \\
7 \\
23\end{array}$ & $\begin{array}{c}31 \\
20 \\
83(12) \\
100 \\
27 \\
38\end{array}$ & $\begin{array}{l}10 \\
7\end{array}$ & $\begin{array}{l}4 \\
4\end{array}$ & $\begin{array}{l}17 \\
14\end{array}$ \\
\hline 9 & $\begin{array}{l}4 \text { strains } \\
\text { *PN-137 } \\
\text { PN-136 }\end{array}$ & $\begin{array}{l}38 \cdot 5(0 \cdot 3) \\
38 \cdot 2 \\
39 \cdot 8\end{array}$ & 16 & 4 & 9 & 11 & 13 & 8 & 10 & 9 & 10 & $\begin{array}{c}81(11) \\
100 \\
26\end{array}$ & $\begin{array}{c}13(3) \\
9 \\
17\end{array}$ & 12 \\
\hline 10 & $\begin{array}{l}4 \text { strains } \\
\text { PN-57 } \\
\text { *DSM } 485 \\
\text { PN-100 }\end{array}$ & $\begin{array}{l}38 \cdot 2(0 \cdot 2) \\
36 \cdot 2 \\
37 \cdot 0 \\
37 \cdot 8\end{array}$ & 39 & 12 & 16 & 17 & 18 & 5 & 16 & 13 & 15 & $\begin{array}{c}15(8) \\
6 \\
24 \\
9\end{array}$ & $\begin{array}{l}75(12) \\
109 \\
100 \\
57\end{array}$ & 25 \\
\hline 11 & $\begin{array}{l}5 \text { strains } \\
\text { *PN-109 } \\
\text { PN-113 }\end{array}$ & $\begin{array}{l}41 \cdot 3(0 \cdot 3) \\
41 \cdot 2 \\
41 \cdot 2\end{array}$ & 26 & 8 & 22 & 30 & 31 & 9 & 30 & 19 & 16 & 19 & 3 & $\begin{array}{c}88(9) \\
100 \\
41\end{array}$ \\
\hline $\begin{array}{l}\text { Single } \\
\text { isolates } \$\end{array}$ & PN-50 & $34 \cdot 0$ & 5 & 5 & 14 & 11 & 12 & 10 & 9 & 10 & 17 & 18 & 14 & 8 \\
\hline
\end{tabular}

† Strains within clusters are given in Table 1. Strains with more than $65 \%$ sequence homology to the reference strain have been grouped and the mean hybridization value is given. Asterisks show the reactions of the reference strain of the cluster and this strain is included in the group value.

$¥$ Although strain PN-57 was recovered as a single-membered cluster in Fig. 1 it was included here as a member of cluster 10 .

$\int$ These data for single-membered clusters represent a single strain but are typical of the data for all the single-membered clusters shown in Table 1.

logical studies (data not shown) revealed that these bacteria and those of phenon 2 were unique among all the taxa studied in being unable to grow in the absence of sodium ions. They were also unable to grow at $\mathrm{pH} 7$ and showed an optimum for growth at $\mathrm{pH} 10$. A distinctive feature of these bacteria was their inability to hydrolyse 
1901

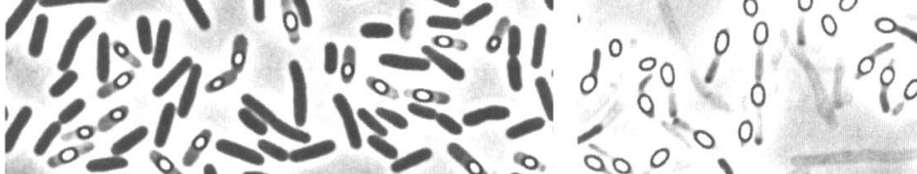

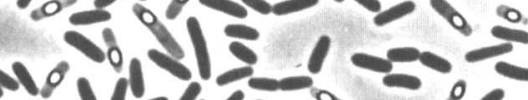

ais 哟

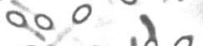
0

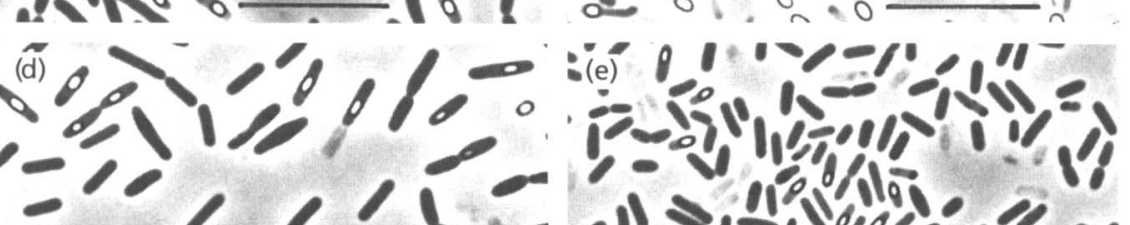

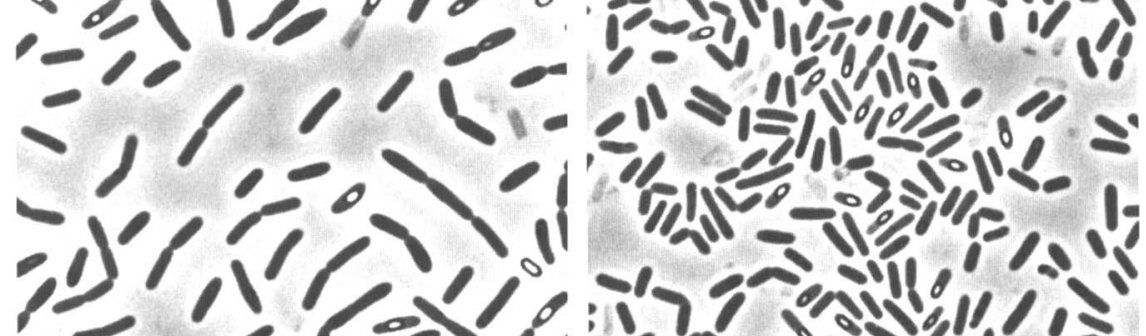
二=-二,

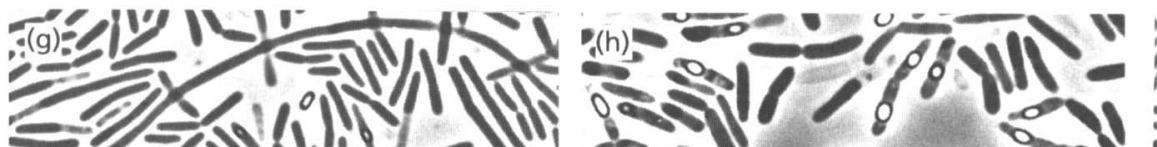

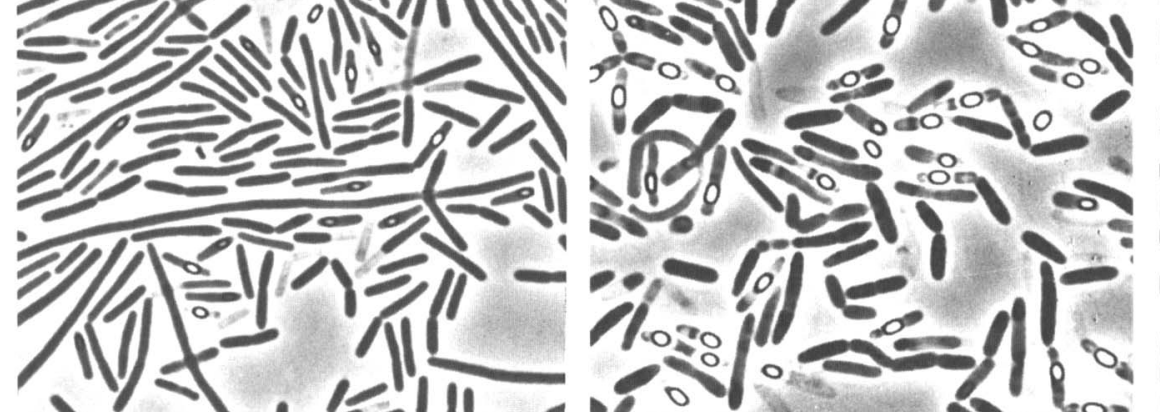
$1 \rightarrow 1=11=0$ 1 Th $=$ 1

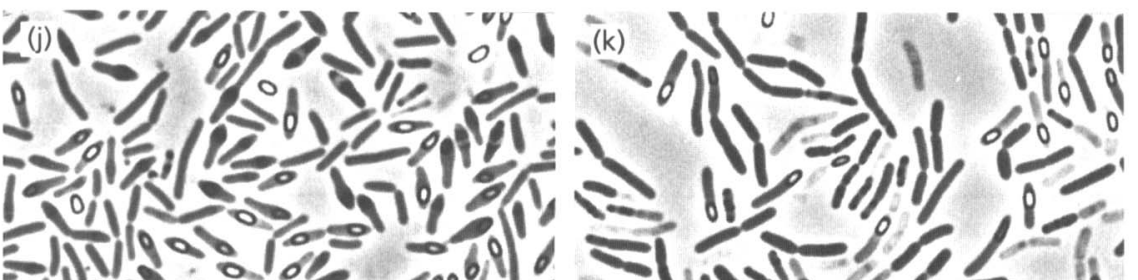

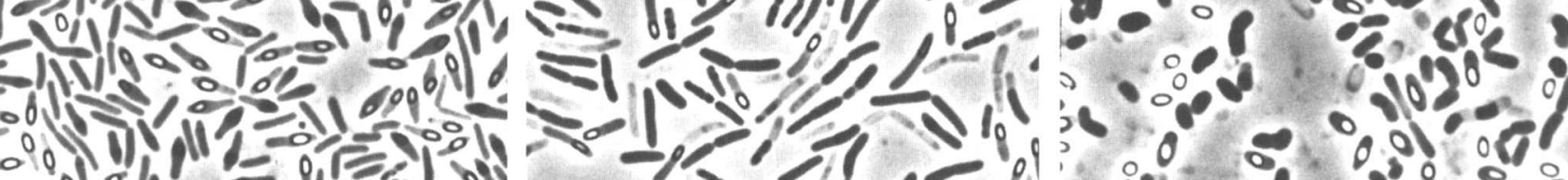

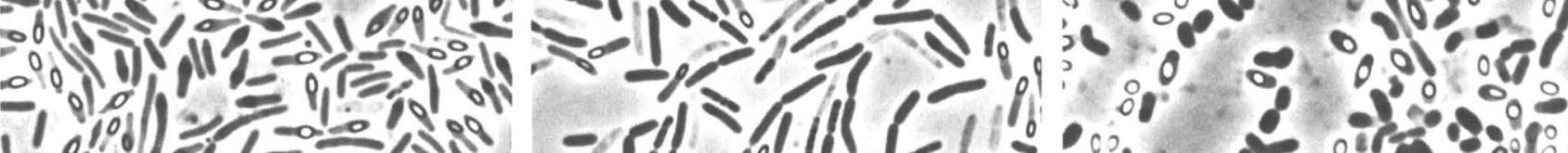

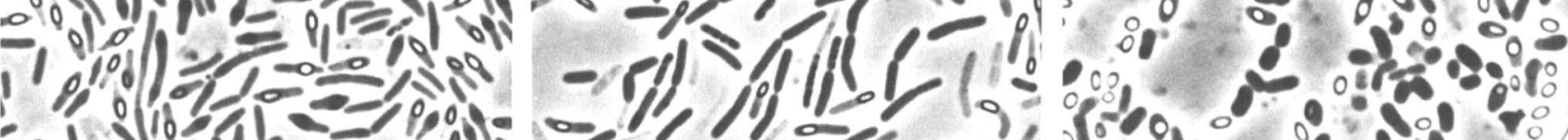

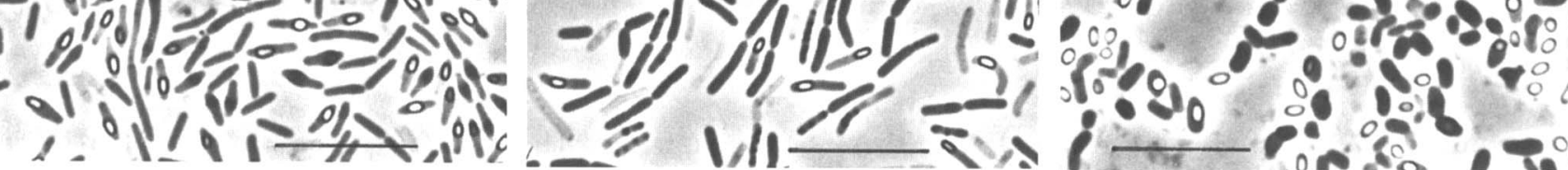


starch. The reference strain produced oval endospores in a clearly swollen sporangium (Fig. 2c).

Phenon 4. This heterogeneous cluster comprised strains allocated to two DNA hybridization groups as well as a single strain which was excluded from these groups (Table 4). The three group 4a strains were largely from soil while the five group 4b strains originated from animal manures. Reference strains from both taxa produced oval endospores which did not swell the sporangia (Fig. 2d, e). The physiological tests and the carbon utilization tests distinguished these taxa but there were no definitive features. Group 4a strains were less temperature tolerant than those of $4 \mathrm{~b}$. Utilization of amygdalin, gentiobiose and mannose also provided some distinction between these groups. DNA analysis showed that group 4a strains were slightly lower in $G+C$ content $(38.4-38.8 \mathrm{~mol} \%)$ than group $4 \mathrm{~b}$ strains $(39 \cdot 2-39 \cdot 7 \mathrm{~mol} \%)$.

Phenon 5. The strains in this phenon formed a homogeneous cluster at $90 \% S_{\mathrm{J}}$ which was supported by the DNA hybridization studies, with only five of the 21 strains showing less than $65 \%$ reassociation to the reference strain. 'Bacillus alcalopbilus subsp. balodurans' DSM 497 was included in this cluster and therefore its name is used for this group. The slightly swollen sporangia containing oval endospores are shown in Fig. 2(f). The organisms largely originated from animal manure and chicken yard soils and were distinctive in their ability to grow at $55^{\circ} \mathrm{C}$. In spite of the subspecific name balodurans, these bacteria had only moderate tolerance to $\mathrm{NaCl}$ (around 12\%) in comparison to other groups. However, the name is to be construed in the context of B. alcalophilus, which has much lower tolerance to $\mathrm{NaCl}$ (Boyer $e$ t al., 1973).

Phenon 6. Of the nine strains in phenon 6, three showed less than $65 \%$ DNA hybridization with the reference strain and only one less than $60 \%$. The long rods typical of the reference strain are shown in Fig. 2(g). These strains had the highest $\mathrm{G}+\mathrm{C}$ content of all the organisms included in the study $(43.7 \mathrm{~mol} \%)$. They reduced nitrate, were unable to hydrolyse Tween or pullulan, and were fairly sensitive to $\mathrm{NaCl}$.

Phenon 7. This phenon was identified as $B$. cobnii and included several strains from the Wadi Natrun in Egypt and from Mono Lake (California). These strains were excluded from the DNA study because they have been characterized previously (Spanka \& Fritze, 1993). Our results confirm the conclusions of the earlier study and emphasize the relatively weak $\mathrm{NaCl}$ tolerance of these bacteria.

Phenon 8. The low level at which phenon 8 was defined in the $S_{\mathrm{J}} / \mathrm{UPGMA}$ analysis was highlighted by the DNA hybridization study, which revealed two groups of strains and two further strains which were unrelated to these groups but could be related to each other (they share the same base composition; see Table 4). Group 8a (two strains) could be distinguished from group $8 \mathrm{~b}$ (four strains) by consistent differences in base composition of DNA and the sensitivity of the former strains to $5 \%$ $\mathrm{NaCl}$. Moreover, strains of group $8 \mathrm{a}$, in contrast to most strains of group 8b, failed to hydrolyse Tween 40 and 60 and to grow on glycerol. There were differences in carbohydrate utilization patterns between strains of groups $8 \mathrm{a}$ and $8 \mathrm{~b}$, particularly with regard to amygdalin and $N$-acetylglucosamine utilization. Morphologically, the reference strains of the two groups were similar but not identical (Fig. 2h, i).

Phenon 9. One of the five phenon 9 strains was unrelated to the reference strain by DNA hybridization and had a slightly higher DNA base composition than other members of the cluster (Table 4). These bacteria failed to grow at $\mathrm{pH} 7$ or above $\mathrm{pH} 10$ and at temperatures above $40{ }^{\circ} \mathrm{C}$. They were tolerant to moderate concentrations of $\mathrm{NaCl}(10 \%)$. The reference strain produced oval endospores in a slightly swollen sporangium (Fig. $2 \mathrm{j}$ ).

Phenon 10. This phenon comprised six strains, of which four showed $>74 \%$ DNA reassociation to $B$. alcalophilus DSM $485^{\mathrm{T}}$, one showed only $57 \%$ and the sixth did not yield high-quality DNA. The strains in this group showed very similar physiological properties to those of phenon 9 but were less salt tolerant (growth up to $8 \% \mathrm{NaCl}$ ) and had a slightly lower $\mathrm{G}+\mathrm{C}$ content. Typical morphology of these cells is shown in Fig. 2(k).

Phenon 11. The six strains in phenon 11 were notable for their homogeneous base composition $(41.1 \mathrm{~mol} \% \mathrm{G}+\mathrm{C})$, with only one strain showing less than $65 \%$ DNA hybridization to the reference strain. Phenotypically, they were characterized by lack of starch and pullulan hydrolysis, relatively low tolerance to $\mathrm{NaCl}$ and inability to grow at $40^{\circ} \mathrm{C}$ or above. The distinctive short fat cells of the reference strain containing oval endospores are shown in Fig. 2(1).

Single-membered clusters. Nine strains were recovered in single-membered clusters and two in a doublet in the $S_{\mathrm{J}} /$ UPGMA analysis. To determine if these bacteria were foci of new clusters or aberrant members of extant clusters, DNA was prepared and hybridized to the DNA from the reference strains of the 11 clusters. Except for strain PN-57, which was allocated to the DNA hybridization group of phenon 10 , there was no significant hybridization of the DNA from the single-membered clusters to any of the reference DNAs. This confirmed that the majority of these bacteria did not belong to any of

\footnotetext{
Fig. 2. Sporulating and non-sporulating cells of representative strains of DNA hybridization groups established in this study. Growth conditions: M1, alkaline nutrient agar supplemented with $5 \mathrm{~g} \mathrm{NaCl} \mathrm{I}^{-1}$ and $10 \mathrm{mg} \mathrm{Mn}^{2+} \mathrm{ml}^{-1} ; \mathrm{M}_{2}$, alkaline nutrient agar supplemented with $5 \mathrm{~g} \mathrm{NaCl} \mathrm{I}^{-1}$ and with $50 \%$ of the water substituted with soil extract. Bars, $10 \mu \mathrm{m}$. (a) Strain PN-3 (group 1): M1, $1 \mathrm{~d}, 30^{\circ} \mathrm{C}$. (b) Strain PN-105 (group 2): M1, $1 \mathrm{~d}, 30^{\circ} \mathrm{C}$ and $4 \mathrm{~d}, 18^{\circ} \mathrm{C}$. (c) Strain PN-102 (group 3): $\mathrm{M} 1,2 \mathrm{~d}, 30^{\circ} \mathrm{C}$. (d) Strain PN-1 (group 4a): M1, $1 \mathrm{~d}, 30^{\circ} \mathrm{C}$. (e) Strain PN-26 (group 4b): $\mathrm{M} 2,36 \mathrm{~h} 30^{\circ} \mathrm{C}$. (f) Strain PN-30 (group 5): $\mathrm{M1}, 2 \mathrm{~d}, 30^{\circ} \mathrm{C}$. (g) Strain PN-23 (group 6): M2, $3 \mathrm{~d}, 25^{\circ} \mathrm{C}$. (h) Strain PN-118 (group 8a): M1, $2 \mathrm{~d}, 30^{\circ} \mathrm{C}$. (i) Strain PN-121 (group 8b): $M 1,36 \mathrm{~h}, 30^{\circ} \mathrm{C}$. (j) Strain PN-137 (group 9): M1, $1 \mathrm{~d}, 30^{\circ} \mathrm{C}$. (k) Strain DSM 485 (group 10): M1, $2 \mathrm{~d}$, $30^{\circ} \mathrm{C}$. (I) Strain PN-109 (group 11): $\mathrm{M} 1,4 \mathrm{~d}, 30^{\circ} \mathrm{C}$.
} 
the clusters shown in Fig. 1 (data not shown). Moreover, the possibility that these bacteria may be related to each other but failed to cluster in the phenogram was excluded by preparing partial $16 \mathrm{~S} \mathrm{rRNA}$ sequences and analysing them in the context of the full sequences for the reference strains (Nielsen $e t$ al., 1994). All of the partial sequences were recovered independently in the phylogenetic tree (data not shown), confirming that they were indeed foci of new species for which we had only single representatives.

\section{DISCUSSION}

When faced with a heterogeneous collection of bacteria, the construction of a basic taxonomic framework from which detailed studies of species can be initiated is sometimes a daunting task. Numerical phenetics has become established as a rapid and reliable procedure for generating this initial database in most instances. For example, numerical analysis of Streptomyces established the framework for future taxonomic studies of species within this genus (Williams et al., 1983) and a recent numerical analysis of the thermophilic Bacillus strains (White et al., 1993) established species which were subsequently evaluated by DNA reassociation and independently by comparative rRNA sequence analysis (Rainey et al., 1994). This current assessment of the diversity of the alkaliphilic Bacillus strains confirms numerical phenetics as an ideal approach for gauging the species diversity within a group of bacteria and indicating reference strains for molecular analyses since, with only a few exceptions, the phena defined by the $S_{\mathrm{J}} /$ UPGMA analysis were fully substantiated by $\mathrm{DNA}$ reassociation and $\mathrm{rRNA}$ sequencing (Nielsen et al., 1994).

When using numerical phenetics in this way, it is a benefit if a minimum of tests can be used and, wherever possible, these can be based on test kits or automated systems. We have confirmed previous numerical analyses (e.g. Priest $e t$ al., 1981) which showed that accurate clustering can be detected with fewer than 50 characters, the only problem being that with this reduced database some taxa are not separated. Thus in the above-mentioned study, $B$. amyloliquefaciens could not be distinguished from $B$. subtilis and individual B. sphaericus DNA hybridization groups were indistinguishable. Similarly, in this study, clusters 4 and 8 were shown to be heterogeneous by DNA hybridization. Such lack of resolution is to be expected from such a small number of tests (Sneath \& Sokal, 1973) and it is likely that with more characters these taxa would have been separated.

API test systems have been used successfully for the classification and identification of Bacillus strains (Logan \& Berkeley, 1984). However, some alkaliphilic Bacillus strains, notably those from clusters 2 and 7 , were unable to produce a detectable reaction in the API tests even though the system had been modified for use at high $\mathrm{pH}$. Given the problems of conducting physiological tests at extremes of $\mathrm{pH}$, this was not surprising and illustrates the difficulties involved. For these reasons, in some previous taxonomic studies of these bacteria, the organisms were first 'adapted' to growth at $\mathrm{pH} 7$ and all tests were

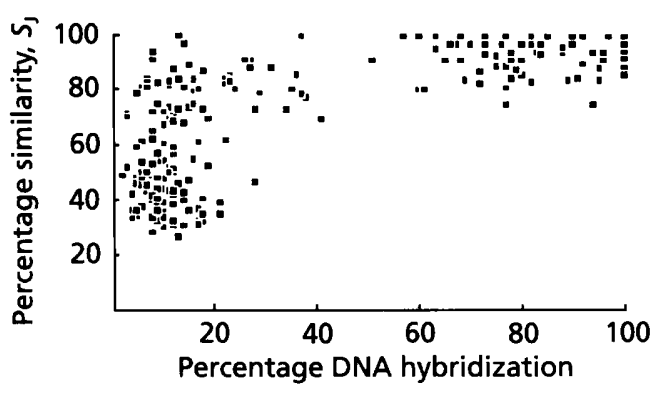

Fig. 3. Comparison of phenotypic similarity calculated from the $S$, coefficient with DNA hybridization for 230 pairs of strains.

performed at neutrality (Gordon \& Hyde, 1982). However, this is an artificial answer to the problem and may lead to erroneous physiological reactions.

The numerical analysis was evaluated by determination of the DNA base composition of all the strains in the study and extensive DNA hybridization reactions. In addition to revealing the heterogeneity of clusters 4 and 8 , the DNA reassociation reactions also showed that most clusters contained strains which were genomically unrelated, but in all cases these were a minority of strains. We defined DNA hybridization groups at $65 \%$, which is $5 \%$ below the currently accepted guideline used in the species definition (Wayne et al., 1987), but given the error rates of around $10 \%$ (standard deviation) for our determinations using an immobilized assay, we consider this acceptable. Indeed, this limit was shown to be appropriate by plotting percentage DNA/DNA reassociation against phenetic similarity determined by $S_{J}$ for 230 pairs of strains (Fig. 3). Although similar results have been presented previously (Staley \& Colwell, 1973) they have not been based on so many determinations and do not show so clearly the cut-off of 'species pairs' at a little above $60 \%$ DNA hydridization and greater, with most non-homologous pairs showing less than $40 \%$ binding. This provides good evidence for the discontinuous spread of DNA hybridization values among these bacterial species and for the use of DNA hybridization for speciation. However, exact definition of the level of DNA hybridization for the species boundary and the difficulties presented by subspecies remain problematic.

It is clear from Fig. 3 that pairs of bacterial strains which show $>65 \%$ DNA hybridization invariably show high phenotypic relatedness as judged by $S_{\mathrm{J}}$ and that most strains which show low DNA relatedness present 25-60\% phenetic similarity. However, some strains which were phenotypically similar were genomically unrelated. This is probably a result of the limited phenotypic database and reflects the problems associated with heterogeneous clusters. It would be interesting to repeat this exercise with a full numerical taxonomic database, in which case it is likely that these aberrant strains would be correctly placed.

It is also useful to compare the DNA hybridization data with the full 16S rRNA sequence similarities which are 


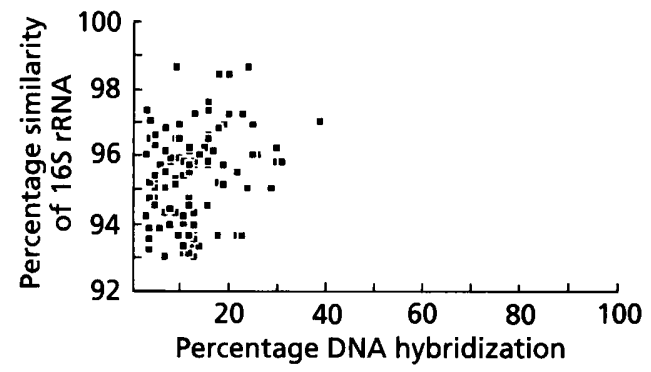

Fig. 4. Comparison of sequence similarity based on the full 165 rRNA sequence (Nielsen et al., 1994) with DNA hybridization for representative alkaliphilic Bacillus strains.

available from our previous study (Nielsen et al., 1994). The data in Fig. 4 include only genomically unrelated strains since strains with high DNA hybridization should have virtually identical rRNA sequences. The scatter of points is similar to that obtained by Amann et al. (1992) for Fibrobacter strains and for Desulfovibrio by Devereux $e t$ al. (1990), and shows that at below approximately $99 \%$ rRNA similarity DNA hybridization is below $50 \%$ and that strains with rRNA similarities at this level definitely represent distinct genospecies. In contrast to the previous studies, there was no indication that pairs of strains showing rRNA similarity below $94 \%$ show lower DNA hybridization than those with rRNA similarity between 94 and $99 \%$. It has been suggested that these lower values could be equated with the generic boundary (Amann et al., 1992).

The phylogenetic positions of all 13 alkaliphilic genospecies which have been defined in this study have been reported by Nielsen et al. (1994). Strains which had been included in previous phenetic taxonomic studies were mainly recovered in phena $1,4 a, 4 b, 5,6,7$ and 10 , with one new isolate each being assigned to phena 1 and 6 and two to phenon 10. All strains of phena 2, 3, 8a, 8b and 11 were provided by H. Outtrup (Novo Nordisk, Denmark), as were the four new isolates mentioned above, and only limited information from previous studies is available for these strains. Phenon 7 strains were identified as $B$. cobnii and related taxa (Spanka \& Fritze, 1993) and are not further discussed; other taxa are discussed separately below.

Phenon 1 (DNA hybridization group 1) contained strains which had previously been identified as $B$. firmus (Gordon \& Hyde, 1982), although strain PN-77 was an exception since it had been classified originally as a $B$. firmus $-B$. lentus intermediate (Gordon \& Hyde, 1982). All of these strains, including PN-77, were classified as phenotypic group 1 by Fritze et al. (1990). These bacteria are phylogenetically unrelated to B. firmus (Nielsen et al., 1994) and their mean DNA base composition is slightly lower than that for $B$. firmus $39.6 \mathrm{~mol} \%$ against about $41 \mathrm{~mol} \%$; Fahmy et al., 1985; Fritze et al., 1990). Moreover, unlike B. firmus, most of these bacteria are unable to grow at $\mathrm{pH} 7$, are tolerant of very high levels of $\mathrm{NaCl}$, and deaminate phenylalanine, a variable feature for B. firmus sensu stricto (Gordon et al., 1973; Priest et al., 1988). They therefore represent a new species for which we recommend the name ' $B$. pseudofirmus'.

Strains in clusters 2 and 3 were phylogenetically removed from all other bacilli. The closest relatives were $B$. alcalophilus DSM $485^{\mathrm{T}}$ and strains representing clusters 1 , 4a, 4b, 5, 6, 9 and 11 of this study (Nielsen et al., 1994). DNA hybridization confirmed that these clusters comprise separate taxa at the species level and they were unique in this study in requiring sodium ions for growth. We suggest the names ' $B$. agaradbaerens' and ' $B$. clarkii' for clusters 2 and 3 respectively.

Phenon 4 was divided into two hybridization groups but both contained strains which had previously been classified as B. lentus type I (Gordon \& Hyde 1982) or phenotypic group 4 (Fritze et al., 1990). These bacteria were unrelated to $B$. lentus phylogenetically (Nielsen $e t$ al., $1994)$ and had a higher DNA base composition than $B$. lentus strains (38-39 $\mathrm{mol} \% \mathrm{G}+\mathrm{C}$ versus $36 \mathrm{~mol} \%$ for the type strain of B. lentus; Fahmy et al., 1985). Unlike B. lentus, these bacteria were proteolytic and grew in $10 \%$ $\mathrm{NaCl}$; they cannot therefore be included in this species. Phenon 4 comprised two DNA hybridization groups and the reference strains were unrelated by $16 \mathrm{~S}$ rRNA sequence analysis (Nielsen et al., 1994). Although these molecular features clearly support two independent and separate taxa, the phenetic data are insufficient to provide diagnostic features at present. The only indications of differing phenotypic properties are the inability of group 4a strains to grow at $40{ }^{\circ} \mathrm{C}$ while $4 \mathrm{~b}$ strains grow at $42{ }^{\circ} \mathrm{C}$, and the slightly larger size of strain PN-1 (4a) cells. To comply with the recommendations of the Ad Hoc Committee on Reconciliation of Approaches to Bacterial Systematics (Wayne et al., 1987), we refrain from naming these taxa until more strains have been isolated and further diagnostic features are available. The proposed reference strain for taxon 4a is PN-1 (= DSM $8714=$ NCIMB 10291); that for 4b is PN-26 (= DSM $8717=$ NCIMB 10288).

DNA hybridization group 5 comprised 16 strains, including ' $B$. alcalophilus subsp. balodurans' (Boyer et al., 1973). These strains were previously assigned to $B$. lentus type III (Gordon \& Hyde, 1982) and phenotypic group 4 (Fritze et al., 1990). Again, rRNA sequence unrelatedness (Nielsen et al., 1994) and gross difference in $\mathrm{mol} \% \mathrm{G}+\mathrm{C}$ ( $42.6 \%$ for phenon 5 strains) exclude these bacteria from $B$. lentus as well as $B$. alcalopbilus. We propose to revive the name balodurans, in the new combination ' $B$. halodurans', for these bacteria.

All strains of DNA hybridization group 6 were previously assigned to B. lentus type II by Gordon \& Hyde (1982) and to phenotypic group 3 by Fritze et al. (1990). These bacteria are distinct from $B$. lentus on the basis of their rRNA sequences (Nielsen et al., 1994), in DNA base composition ( $43.7 \mathrm{~mol} \% \mathrm{G}+\mathrm{C}$ ), and in several phenotypic attributes such as casein hydrolysis, nitrate reduction and ability to grow at $50{ }^{\circ} \mathrm{C}$ (all negative for $B$. lentus and 
positive for DNA hybridization group 6). We therefore propose that these bacteria should be assigned to a new species, for which the name ' $B$. clausii' is recommended.

Two independent DNA hybridization groups were defined within phenon 8 strains. Again, the distinct positions of the reference strains according to rRNA sequence analysis underline the validity of these taxa. Although diagnostic phenotypic features are scarce, growth in $5 \% \mathrm{NaCl}$ and cell morphology (group 8a strains are considerably larger than $8 \mathrm{~b}$ strains) consistently separate these groups and therefore we propose both as new species: ' $B$. halmapalus' for taxon 8 a strains and ' $B$. borikoshii' for taxon $8 \mathrm{~b}$ strains.

Clusters 9 and 10 were two further taxa which were difficult to separate phenotypically. Virtually all strains of both phena were recovered in their corresponding DNA hybridization groups and the reference strains had distinct positions according to rRNA sequence analysis. However, the higher $\mathrm{NaCl}$ tolerance of group 9 strains compared with those of group 10 and the distinctly swollen sporangia of the former strains provide two easily determined and definitive features for identification. Group 10 strains represent the species B. alcalophilus and the data presented here are used to provide an emended description of this previously monotypic species. We propose the name 'B. pseudalcalophilus' for group 9 strains in recognition of their close phenotypic and phylogenetic relationship with B. alcalophilus.

Phenon 11 strains were well defined phenotypically, by DNA hybridization and by RNA sequence analysis (Nielsen et al., 1994). Lack of starch and pullulan hydrolysis and low $\mathrm{pH}$ optimum and $\mathrm{NaCl}$ tolerance for growth are characteristic of these bacteria. The name ' $B$. gibsonii' is proposed for these organisms.

\section{NOMENCLATURE}

\section{Emended description of Bacillus alcalophilus (Vedder, 1934)}

This description is based on the strains of DNA hybridization group 10 of this study. Colonies are white, circular, smooth and shining, sometimes with a darker centre. Cells are rod-shaped $(0.5-0.7 \times 3.0-5.0 \mu \mathrm{m})$, producing ellipsoidal endospores $(0.5-0.7 \times 0.9-1.3 \mu \mathrm{m})$ which are located subterminally and do not swell the sporangium. Strains of this species hydrolyse casein, gelatin, pullulan, starch, Tween 40 and Tween 60 . They do not hydrolyse hippurate, MUG or Tween 20 (strain PN-138 is weakly positive). Nitrate is not reduced to nitrite (strain PN-101 is an exception) and strains do not deaminate phenylalanine. No growth is observed at

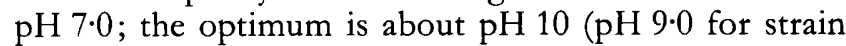
PN-57). The temperature range for growth is $10-40{ }^{\circ} \mathrm{C}$. There is a variable reaction to $\mathrm{NaCl}$ : the type strain and strain $\mathrm{PN}-57$ are sensitive to $5 \% \mathrm{NaCl}$ but other strains tolerate $8 \% \mathrm{NaCl}$. Carbon source utilization profiles showed that strains use L-arabinose, melibiose and rhamnose for growth. The chromosomal DNA base composition is $36 \cdot 2-38 \cdot 4 \mathrm{~mol} \% \mathrm{G}+\mathrm{C}$.
Source: soil and faeces.

Type strain: DSM 485.

\section{Description of Bacillus agaradhaerens sp. nov.}

Bacillus agaradhaerens (a.gar.ad'hae.rens) sp. nov. Malayan $\mathrm{n}$. agar gelling polysaccharide from brown algae; $\mathrm{L}$ adj. adhaerens adherent; ML adj. agaradbaerens adhering to the agar which is characteristic of these colonies.

This description is taken from this paper for DNA hybridization group 2 and unpublished results of $\mathrm{H}$. Outtrup. Colonies are white and rhizoid with a filamentous margin. Cells are rod-shaped $(0.5-0.6 \times 2-5 \mu \mathrm{m})$ and produce ellipsoidal spores $(0.6-1.0 \times 1.0-1.6 \mu \mathrm{m})$ subterminally positioned within a sporangium, which is clearly swollen. Strains of this species are characterized by hydrolysis of Tween 40 and 60 (PN-105 is negative for the former) casein, gelatin, starch, cellulose and xylan. Hippurate, MUG and Tween 20 are not hydrolysed and phenylalanine is not deaminated. Nitrate is reduced to nitrite. Strains of this species are strictly alkaliphilic: no growth is observed at $\mathrm{pH} 7.0$ and optimal growth is observed at $\mathrm{pH} 10.0$ or above. Growth occurs within a temperature range of $10-45{ }^{\circ} \mathrm{C}$. Tolerance to $16 \% \mathrm{NaCl}$ is observed (strain PN-107 grows only weakly at this $\mathrm{NaCl}$ concentration). Carbohydrate utilization profiles show growth on L-arabinose, galactose, mannose, $N$ acetylglucosamine or 2-ketogluconate and most strains grow on tagatose but no growth on methyl $\beta$-D-xyloside, inositol or xylitol is observed. The chromosomal DNA composition is between $39 \cdot 3$ and $39 \cdot 5 \mathrm{~mol} \% \mathrm{G}+\mathrm{C}$.

Source: soil.

Type strain of this species is PN-105 (= DSM 8721).

\section{Description of Bacillus clarkii sp. nov.}

Bacillus clarkii (clar'ki.i) sp. nov. ML gen. n. clarkii from Clark, named after the American bacteriologist Francis E. Clark, who made pioneering studies on the taxonomy of endospore-forming bacteria.

This description is taken from the current study based on strains of DNA hybridization group 3. Colonies are circular with an entire margin and a smooth surface and a cream-white to pale yellow colour (strain PN-104 eventually changes to a dark yellow colour, probably due to synthesis of an excreted pigment). Cells are rod-shaped $(0.6-0.7 \times 2.0-5.0 \mu \mathrm{m})$ and produce ellipsoidal spores $(0.6-1 \cdot 0 \times 0.7-1.2 \mu \mathrm{m})$ located subterminally. In the type strain, the sporangium is distinctly swollen by the spore. Strains of this species hydrolyse casein, hippurate, gelatin, Tween 40 (strain PN-104 weakly positive) and Tween 60 . Starch, MUG, Tween 20 and pullulan are not hydrolysed. Growth is strictly alkaliphilic: no growth is observed at $\mathrm{pH} \mathrm{7.0} \mathrm{and} \mathrm{optimal} \mathrm{growth} \mathrm{is} \mathrm{above} \mathrm{pH} 10 \cdot 0$. Growth is observed between 15 and $45^{\circ} \mathrm{C}$ and strains are tolerant to $16 \% \mathrm{NaCl}$. No growth is observed in minimal medium for carbohydrate utilization at $\mathrm{pH} 10 \cdot 0$. The chromosomal DNA composition is between $42 \cdot 4$ and $43.0 \mathrm{~mol} \% \mathrm{G}+\mathrm{C}$. 
Source: soil.

Type strain of this species is PN-102 (= DSM 8720).

\section{Description of Bacillus clausii sp. nov.}

Bacillus clausii (clau'si.i) sp. nov. ML gen. n. clausii of Claus; named after Dieter Claus, the German bacteriologist who made fundamental contributions to the taxonomy of Bacillus.

The description given below is taken from this study for DNA hybridization group 6 strains. Colonies are white and filamentous with a filamentous margin. Cells are rodshaped $(0.5-0.7 \times 2.0-4.0 \mu \mathrm{m})$, producing spores which are ellipsoidal $(0.4-0.6 \times 0.7-1.0 \mu \mathrm{m})$ and located subterminally to paracentrally in the sporangium, which may be slightly swollen. Cells tend to occur in long chains which may carry spores. The strains in this species are characterized by hydrolysis of casein, gelatin and starch, but not pullulan, Tween 20,40 or 60 or MUG. Nitrate is reduced but phenylalanine is not deaminated. The $\mathrm{pH}$ optimum is about 8 , and good growth is obtained at $\mathrm{pH} 7 \cdot 0$. Growth at temperatures from 15 to $50^{\circ} \mathrm{C}$ is observed, with salt tolerance up to about $10 \% \mathrm{NaCl}$ (strain PN-76 tolerates only $8 \% \mathrm{NaCl}$ ). Carbohydrate utilization patterns show growth on L-arabinose, galactose, xylitol, dulcitol, sorbitol, methyl $\alpha$-D-mannoside, mannose, $N$-acetylglucosamine, D-tagatose or 2-ketogluconate. Some strains grow on inositol. The chromosomal DNA composition is between $42 \cdot 8$ and $45 \cdot 5 \mathrm{~mol} \% \mathrm{G}+\mathrm{C}$.

Source: soil.

Type strain of this species is PN-23 (= DSM $8716=$ NCIMB 10309).

\section{Description of Bacillus gibsonii sp. nov.}

Bacillus gibsonii (gib.so'ni.i) sp. nov. L gen. n. from Gibson, named after the British bacteriologist Thomas Gibson, who made fundamental contributions to the taxonomy of Bacillus.

The description is taken from the current study for strains of DNA hybridization group 11. Colonies are yellow and circular with an entire margin and a smooth, shiny surface. Cells are usually stout rods $(0 \cdot 6-1.0 \times 2.0-3.0 \mu \mathrm{m})$ with ellipsoidal spores $(0.6-1.0 \times 0.8-1.6 \mu \mathrm{m})$ situated subterminally and in ageing cells paracentrally to sometimes lateral. Spores do not cause swelling of the sporangium. Strains of this species hydrolyse casein, gelatin and MUG. Some strains, but not the type strain, hydrolyse Tween 40 and 60 . No hydrolysis of starch or pullulan is observed, phenylalanine is not deaminated and reduction of nitrate is variable among strains. Growth occurs at $\mathrm{pH} 7 \cdot 0$, with an optimum at about $\mathrm{pH} 8.0$. Strains grow in the temperature range from 10 to $37^{\circ} \mathrm{C}$, with the type strain failing to grow at $37^{\circ} \mathrm{C}$. All strains tolerate up to $9 \% \mathrm{NaCl}$, while strain $\mathrm{PN}-111$ grows at $12 \% \mathrm{NaCl}$. Carbohydrate utilization pattern shows growth on lactose, but not on glycogen or $N$ acetylglucosamine. The chromosomal DNA composition is between 40.6 and $41.7 \mathrm{~mol} \% \mathrm{G}+\mathrm{C}$.
Source: soil.

Type strain of this species is PN-109 (= DSM 8722).

\section{Description of Bacillus halmapalus sp. nov.}

Bacillus balmapalus (hal.ma'pa.lus) sp. nov. Gr. n. balme, brine; Gr. adj. bapalos, delicate; ML adj. balmapalus, sensitive to brine.

This description is taken from this study based on strains of cluster 8a. Colonies are small, circular with an entire margin, shiny surface and a cream-white colour. Cells are rod shaped $(0.6-1.0 \times 3.0-4.0 \mu \mathrm{m})$ with ellipsoidal spores $(0.6-0.8 \times 0.9-1.5 \mu \mathrm{m})$ located subterminally to paracentrally not swelling the young sporangium. The two strains in this species hydrolyse casein, gelatin, hippurate, pullulan and starch. They do not hydrolyse Tween 20, 40 and 60 or MUG. They grow at $\mathrm{pH} 7 \cdot 0$, with an optimum at about $\mathrm{pH} 8 \cdot 0$. Growth is observed between 10 and $40^{\circ} \mathrm{C}$. Salt tolerance is very low, with no growth in the presence of $5 \% \mathrm{NaCl}$. Carbohydrate utilization profiles show no growth on glycerol, ribose, D-xylose, L-arabinose, galactose, thamnose, sorbitol, lactose, melibiose, melizitose, D-raffinose or D-tagatose. The chromosomal DNA composition is $38.6 \mathrm{~mol} \% \mathrm{G}+\mathrm{C}$ for the two currently characterized strains.

Source: soil.

Type strain of this species is PN-118 (= DSM 8723).

\section{Description of Bacillus halodurans sp. nov.}

Bacillus halodurans sp. nov., comb. nov., nom. rev. ('Bacillus alcalophilus subsp. balodurans', Boyer et al., 1973) ha.lo.du'rans. Gr. n. bals salt; L pres. part. durans enduring; ML adj. balodurans salt-enduring.

This description is taken from this study for strains of DNA hybridization group 5 and Fritze $e t$ al. (1990) and corresponds largely with the original description. Colonies are white and circular with a slightly filamentous margin. Cells are rod-shaped $(0.5-0.6 \times 3.0-4.0 \mu \mathrm{m})$ and produce spores which are ellipsoidal $(0.5-0.6 \times 0.8-1.2 \mu \mathrm{m})$ and located subterminally in the sporangium, which is slightly swollen. Cells tend to occur in long chains frequently bearing spores. Hydrolysis of Tween 40 and 60 , casein, gelatin, starch and pullulan is obtained. Most strains do not hydrolyse Tween 20 (strains PN-62 and PN-80 positive) or hippurate (strain PN-31 positive), and do not reduce nitrate (strains $\mathrm{PN}-31$ and $\mathrm{PN}-42$ positive). MUG is not hydrolysed and phenylalanine is not deaminated. Most strains grow at $\mathrm{pH} 7 \cdot 0$ (strains $\mathrm{PN}-31$ and PN-42 do not) but optimal growth is obtained around $\mathrm{pH} 9-10$. Growth temperature range is $15-55^{\circ} \mathrm{C}$. Strains show moderate halotolerance; good growth is obtained up to $12 \% \mathrm{NaCl}$. Carbohydrate utilization pattern shows growth on L-arabinose, galactose, xylitol, inositol, mannose, $\mathrm{N}$-acetylglucosamine or 2-ketogluconate, but not with dulcitol, sorbitol, methyl $\alpha$-D-mannoside or $D$-tagatose. The chromosomal DNA composition is between $42 \cdot 1$ and $43.9 \mathrm{~mol} \% \mathrm{G}+\mathrm{C}$. 
Source: Soil.

Type strain of this species is PN-80 (= DSM 497).

\section{Description of Bacillus horikoshii sp. nov.}

Bacillus horikoshii (ho.ri.ko'shi.i) sp. nov. ML gen. n. borikoshii of Horikoshi; named after the Japanese microbiologist Koki Horikoshi, who has made fundamental contributions to the study of alkaliphilic bacteria.

This description is taken from this study based on strains of DNA hybridization group 8b. Colonies are small, circular with an entire margin, shiny surface and a creamwhite colour. Cells are rod-shaped $(0.6-0.7 \times 2.0-4.0 \mu \mathrm{m})$ with ellipsoidal spores $(0.5-0.7 \times 0.7-1.2 \mu \mathrm{m})$ located subterminally in a sporangium which may be slightly swollen. Strains of this species hydrolyse casein, hippurate, gelatin, pullulan and starch. Three of the four strains hydrolyse Tween 40 and 60 . Growth is observed at $\mathrm{pH} 7 \cdot 0$, with an optimum at about $\mathrm{pH} 8 \cdot 0$. Strains grow between 10 and $40^{\circ} \mathrm{C}$. Salt tolerance is moderate, with a maximum at $8-9 \% \mathrm{NaCl}$. Strains do not hydrolyse MUG or Tween 20 , do not deaminate phenylalanine and do not reduce nitrate to nitrite. No growth is observed on ribose, D-xylose, L-arabinose, galactose, rhamnose, sorbitol, lactose, melibiose, melizitose, D-raffinose or D-tagatose. The chromosomal DNA composition is between 41.1 and $42 \cdot 0 \mathrm{~mol} \% \mathrm{G}+\mathrm{C}$.

Source: soil samples.

Type strain of this species is PN-121 (= DSM 8719).

\section{Description of Bacillus pseudalcalophilus sp. nov.}

Bacillus pseudalcalophilus (pseu.dal.ca.lo'phi.lus) sp. nov. Gr. adj. pseudes false; specific epithet alcalophilus; ML adj. pseudalcalophilus, false alcalophilus because it is phenotypically closely related to $B$. alcalophilus but phylogenetically distinct.

The description is taken from this study for strains of DNA hybridization group 9. Colonies are white and circular with an undulate margin. Cells are rod shaped $(0.5-0.6 \times 2.0-4.0 \mu \mathrm{m})$ and produce ellipsoidal spores $(0.5-0.7 \times 0.8-1.3 \mu \mathrm{m})$ which swell the sporangium and are situated paracentrally to subterminally. Strains of this species hydrolyse casein, gelatin, starch and pullulan, but hippurate, MUG and Tween 20 are not hydrolysed. Phenylalanine is not deaminated and nitrate is not reduced. No growth is obtained at $\mathrm{pH} 7 \cdot 0$ and the optimum is about $\mathrm{pH} 10.0$. All strains grow from $10-40{ }^{\circ} \mathrm{C}$. Strains tolerate up to $10 \% \mathrm{NaCl}$. Carbohydrate utilization profiles show growth on $\mathrm{L}$-arabinose or galactose, with some strains able to grow on tagatose or 2 -ketogluconate. No growth is observed on inositol, xylitol, dulcitol, sorbitol, methyl $\alpha$-D-mannoside, $N$ acetylglucosamine or mannose. The chromosomal DNA composition is between $38 \cdot 2$ and $39 \cdot 0 \mathrm{~mol} \% \mathrm{G}+\mathrm{C}$.

Source: soil samples.

Type strain of this species is PN-137 (= DSM 8725).

\section{Description of Bacillus pseudofirmus sp. nov.}

Bacillus pseudofirmus (pseu.do.fir'mus) sp. nov. Gr. adj. pseudes false; specific epithet firmus. ML adj. pseudofirmus the false firmus; referring to physiological similarities to $B$. firmus.

This description is taken from this study for strains of DNA hybridization group 1. Colonies are yellow and round with irregular margins. Cells are rod-shaped $(0.6-0.8 \times 3.0-6.0 \mu \mathrm{m})$, producing spores which are oval $(0.5-0.7 \times 0.5-1.2 \mu \mathrm{m})$ and located centrally to subterminally without swelling the sporangium. The strains in this species are characterized by hydrolysis of Tween 40 and 60 , gelatin, casein and starch. Hippurate, MUG, pullulan (with the exception of PN-3, PN-10 and PN-72) and Tween 20 are not hydrolysed, nitrate is not reduced but all strains deaminate phenylalanine. The strains are strictly alkaliphilic: for most of the strains no growth is obtained at $\mathrm{pH} 7 \cdot 0$ and the optimum is around $\mathrm{pH} 9 \cdot 0$. The strains show growth from 10 to $45^{\circ} \mathrm{C}$. Growth is detected in the presence of up to $16 \% \mathrm{NaCl}$, with most strains tolerating $17 \% \mathrm{NaCl}$. The carbohydrate utilization profile shows growth on ribose or D-xylose, but no growth on L-arabinose, galactose, rhamnose, sorbitol, lactose, melibiose, melizitose, D-raffinose or D-tagatose. The chromosomal DNA composition is between $39 \cdot 0$ and $40 \cdot 8 \mathrm{~mol} \% \mathrm{G}+\mathrm{C}$.

Source: soil and animal manure.

Type strain of this species is PN-3 (= DSM $8715=$ NCIMB 10283).

\section{ACKNOWLEDGEMENTS}

We would like to thank Helle Outtrup for providing us with bacterial strains which were not publicly available. This work was supported by the Danish Research Academy, DSM Deutsche Sammlung von Mikroorganismen und Zellkulturen $\mathrm{GmbH}$, and Novo Nordisk. The experimental work was carried out at DSM and at Department of Biological Sciences, HeriotWatt University. The excellent technical assistance of Katja Weisser is gratefully acknowledged. We thank T. O. Macadoo for assistance with formulation of names.

\section{REFERENCES}

Alexander, B. \& Priest, F. G. (1989). Bacillus glucanolyticus, a new species that degrades a variety of $\beta$-glucans. Int J Syst Bacteriol 39, 112-115.

Amann, R. I., Lin, C., Key, R., Montgomery, L. \& Stahl, D. A. (1992). Diversity among Fibrobacter isolates: towards a phylogenetic classification. Syst Appl Microbiol 15, 23-31.

Ash, C., Farrow, J. A. E., Wallbanks, S. \& Collins, M. D. (1991). Phylogenetic heterogeneity of the genus Bacillus revealed by comparative analysis of small subunit ribosomal RNA sequences. Lett Appl Microbiol 13, 202-206.

Aunstrup, K., Andresen, O. \& Outtrup, H. (1971). UK patent no. 1243784.

Aunstrup, K., Outtrup, H., Andresen, O. \& Dambmann, C. (1972). Proteases from alkalophilic Bacillus species. In Fermentation Technology Today; Proceedings of the 4th International Fermentation Symposium, pp. 299-305. Osaka: Society for Fermentation Technology. Boyer, E. W., Ingle, M. B. \& Mercer, G. D. (1973). Bacillus alcalopbilus 
subsp. balodurans subsp. nov.: an alkaline amylase producing alkalophilic organism. Int J Syst Bacteriol 23, 238-242.

Chislett, M. E. \& Kushner, D. J. (1961). A strain of Bacillus circulans capable of growing under highly alkaline conditions. J Gen Microbiol 24, 187-190.

Demharter, W. \& Hensel, R. (1989). Bacillus thermocloacae sp. nov., a new thermophilic species from sewage sludge. Syst Appl Microbiol 11, 272-276.

Denariaz, G., Payne, W. J. \& Le Gall, J. (1989). A halophilic denitrifier, Bacillus balodenitrificans sp. nov. Int J Syst Bacteriol 39, 145-151.

Devereux, R., He, S.-H., Doyle, C. L., Orkland, S., Stahl, D. A., LeGall, J. \& Whitman, W. B. (1990). Diversity and origin of Desulfovibrio species: phylogenetic definition of a family. $J$ Bacteriol 172, 3609-3619.

Fahmy, F., Flossdorf, J. \& Claus, D. (1985). The DNA base composition of type strains of the genus Bacillus. Syst Appl Microbiol 6, 60-65.

Fritze, D., Flossdorf, J. \& Claus, D. (1990). Taxonomy of alkaliphilic Bacillus strains. Int J Syst Bacteriol 40, 92-97.

Gordon, R. E. \& Hyde, J. L. (1982). The Bacillus firmus-Bacillus lentus complex and the $\mathrm{pH} 7 \cdot 0$ variants of some alkalophilic strains. $J$ Gen Microbiol 128, 1109-1116.

Gordon, R. E., Haynes, W. C. \& Pang, C. H. (1973). The genus Bacillus (Agricultural handbook no. 427). Washington, DC: US Department of Agriculture.

Guffanti, A. A. (1983). ATP-dependent $\mathrm{Na}^{+} / \mathrm{H}^{+}$antiport activity in Bacillus alcalophilus requires generation of an electrochemical gradient of protons. FEMS Microbiol Lett 17, 307-310.

Horikoshi, K. (1971). Production of alkaline enzymes by alkalophilic microorganisms. Part 1. Alkaline protease produced by Bacillus no. 221. Agric Biol Chem 35, 1407-1414.

Horikoshi, K. (1975). Process for producing cyclodextrins. US patent no. 3923598.

Horikoshi, K. (1991). Microorganisms in Alkaline Environments. Weinheim: VCH Verlagsgesellschaft.

Jones, B. E., Grant, W. D., Collins, N. D. \& Mwatha, W. E. (1994). Alkaliphiles: diversity and identification. In Bacterial Diversity and Systematics, pp. 195-230. Edited by F. G. Priest, A. Ramos Cormenzana \& B. Tindall. New York: Plenum Press.

Johnson, J. L. (1981). Genetic characterization. In Manual of Methods for General Bacteriology, pp. 450-472. Edited by G. P. Murray, R. G. E. Murray, R. N. Costilow, E. W. Nester, W. A. Wood, N. R. Krieg \& G. B. Phillips. Washington, DC: American Society for Microbiology.

Kitamoto, N., Kimura, T., Kito, Y. \& Ohmiya, K. (1992). Cloning and sequencing of the gene encoding cyclodextrin glucanotransferase from Bacillus sp. KL201. J Ferment Bioeng 74, 345-351.

Logan, N. A. \& Berkeley, R. C. W. (1984). Identification of Bacillus strains using the API system. J Gen Microbiol 130, 1871-1882.

Mesbah, M., Premachandran, U. \& Whitman, W. B. (1989). Precise measurement of the $\mathrm{G}+\mathrm{C}$ content of DNA by HPLC. Int J Syst Bacteriol 39, 159-167.

Nakamura, S., Wakabayashi, K., Nakai, R., Aono, R. \& Horikoshi, K. (1993). Production of alkaline xylanase by a newly isolated Bacillus sp. YIM-1. World J Microbiol Biotecbnol 9, 221-224.

Nielsen, P., Rainey, F. A., Outtrup, H., Priest, F. G. \& Fritze, D. (1994). Comparative $16 \mathrm{~S}$ rDNA sequence analysis of some alkali- philic bacilli and the establishment of a sixth rRNA group within the genus Bacillus. FEMS Microbiol Lett 117, 61-66.

Niimura, Y., Koh, E., Yanagida, F., Suzuki, K.-I., Komagata, K. \& Kozaki, M. (1990). Amphibacillus xylanus gen. nov., sp. nov., a facultatively anaerobic sporeforming xylan-digesting bacterium which lacks cytochrome, quinone, and catalase. Int J Syst Bacteriol 40, 297-301.

Priest, F. G., Goodfellow, M. \& Todd, C. (1981). The genus Bacillus: a numerical analysis. In The Aerobic Endospore-forming Bacteria: Classification and Identification, pp. 91-103. Edited by R. C.W. Berkeley \& M. Goodfellow. London \& New York: Academic Press.

Priest, F. G., Goodfellow, M. \& Todd, C. (1988). A numerical classification of the genus Bacillus. J Gen Microbiol 134, 1847-1882.

Rainey, F. A., Fritze, D. \& Stackebrandt, E. (1994). The phylogenetic diversity of thermophilic members of the genus Bacillus as revealed by $16 \mathrm{~S}$ rDNA analysis. FEMS Microbiol Lett 115, 205-211.

Scholz, T., Demharter, W., Hensel, R. \& Kandler, O. (1988). Bacillus pallidus sp. nov., a new thermophilic species from sewage. Syst Appl Microbiol 9, 91-96.

Seldin, L. \& Dubnau, D. (1985). Deoxyribonucleic acid homology among Bacillus polymyxa, Bacillus macerans, Bacillus azotofixans, and other nitrogen-fixing Bacillus strains. Int J Syst Bacteriol 35, 151-154.

Skerman, V. B. D., McGowan, V. \& Sneath, P. H. A. (editors) (1980). Approved lists of bacterial names. Int J Syst Bacteriol 30 , 225-420.

Sneath, P. H. A. \& Sokal, R. R. (1973). Numerical Taxonomy. The Principles and Practice of Numerical Classification. San Francisco: W. H. Freeman.

Spanka, R. \& Fritze, D. (1993). Bacillus cobnii sp. nov., a new obligately alkaliphilic oval-spore-forming Bacillus species with ornithine and aspartic acid instead of diaminopimelic acid in the cell wall. Int J Syst Bacteriol 43, 150-156.

Staley, T. E. \& Colwell, R. R. (1973). Application of molecular genetics and numerical taxonomy to the classification of bacteria. Annu Rev Ecol Syst 4, 273-300.

Suzuki, Y., Kishigami, T., Inoue, K., Mizogushi, Y., Eto, N., Takagi, M. \& Abe, S. (1983). Bacillus thermoglucosidasius sp. nov., a new species of obligately thermophilic Bacilli. Syst Appl Microbiol 4, 487-495.

Tamaoka, J. \& Komagata, K. (1984). Determination of DNA base composition by reverse-phase HPLC. FEMS Microbiol Lett 25, 125-128.

Vedder, A. (1934). Bacillus alcalopbilus n. sp.; benevens enkele ervaringen met sterk alcalische voedingsbodems. Antonie Leeuvenboek 1, 143-147

Wayne, L. G., Brenner, D. J., Colwell, R. R., Grimont, P. A. D., Kandler, O., Krichevsky, M. I., Moore, L. H., Murray, R. G. E., Stackebrandt, E., Starr, M. P. \& Truper, H. G. (1987). Report of the ad hoc commitee on reconciliation of approaches to bacterial systematics. Int J Syst Bacteriol 37, 463-464.

White, D., Sharp, R. J. \& Priest, F. G. (1993). A polyphasic study of thermophilic bacilli from a wide geographical area. Antonie Leeunenboek 64, 357-386.

Williams, S. T., Goodfellow, M., Alderson, G., Wellington, E. M. H., Sneath, P. H. A. \& Sackin, M. J. (1983). Numerical classification of Streptomyces and related genera. J Gen Microbiol 129, 1743-1813.

Received 23 December 1994; revised 8 March 1995; accepted 23 March 1995. 